\title{
Bioaccumulation of heavy metals and As in maize (Zea mays $L$ ) grown close to mine tailings strongly impacts plant development
}

ESTHER AURORA RUIZ HUERTA ( $\nabla$ auri_bio@yahoo.com.mx )

Universidad Nacional Autonoma de Mexico https://orcid.org/0000-0002-6295-2221

Maria Aurora Armienta Hernández

Universidad Nacional Autónoma de México: Universidad Nacional Autonoma de Mexico

Joseph G. Dubrovsky

Universidad Nacional Autónoma de México: Universidad Nacional Autonoma de Mexico

Juan Miguel Gómez Bernal

Universidad Autonoma Metropolitana Iztapalapa

\section{Research Article}

Keywords: Tailing, Heavy metal, Plant growth, Bioaccumulation, Morphology

Posted Date: August 19th, 2021

DOI: https://doi.org/10.21203/rs.3.rs-827219/v1

License: (c) (i) This work is licensed under a Creative Commons Attribution 4.0 International License.

Read Full License 


\section{Abstract}

Potentially toxic metals and metalloids present in mining residues can affect ecosystems, particularly plant growth and development. In this study we evaluated As and heavy metal ( $\mathrm{Fe}, \mathrm{Zn}, \mathrm{Cu}, \mathrm{Cd}, \mathrm{Pb})$ contents in maize (Zea mays $\mathrm{L}$ ) plants grown in soils collected near $(40 \mathrm{~m})$, at intermediate $(400 \mathrm{~m})$ and remote $(3000 \mathrm{~m})$ distances from mine tailings near Taxco City, Mexico. Soils sampled near and at intermediate sites from the tailings contained high levels of heavy metals which were 3 - to 55 -fold higher compared to the control samples. The heavy metal and As content in plants reflected the soil contamination being the greatest for most studied elements in root samples followed by stems, leaves, and kernels. Though plants were capable of completing their life cycle and producing the seeds, high bioaccumulation levels had a strong impact on plant development. Abnormalities in the organs like malformations in reproductive structures (tassel and ear), reduction in the phytomer number and the plant height were present. Microscopic studies and morphometric analyses suggest that strongly affected plant growth result from negative and synergistic action of heavy metals and As in soils on cell growth and cell production. This study showed that maize grown near mine tailings accumulates high levels of heavy metals and As which decrease significantly plant yield and could be dangerous if consumed by animals and humans.

\section{Introduction}

Through decades, heavy metal and metalloid contamination caused by industrial activities has raised concerns over environmental quality and public health (Wang et al. 2016; Bostick et al. 2018; Prommer et al. 2018; Chen et al. 2019; Alharbi et al. 2020; Hu et al. 2020; Liu et al. 2020a; Wang et al. 2020a, 2020b, 2020c). Heavy metal pollution is a serious environmental problem because metals are non-biodegradable and consequently accumulate in the environment (Ali et al. 2013; Hu and Cheng 2013). Biogeochemical processes can promote the release of potentially toxic elements and their spread through different pathways to the environment. A wide range of environmental media near mining or smelting areas has been contaminated by heavy metals and metalloids, which threat the health of the ecosystem and human beings (Lin et al. 2012; Wang et al. 2017; Liu et al. 2019a, 2019b, 2020b; Yin et al. 2019; Beiyuan et al. 2020; Li et al. 2020; Zhong et al. 2020), especially by the inappropriate disposal of mine tailings, providing negative effects on the exposed organisms (Tovar-Sánchez et al. 2012; Mussali-Galante et al. 2013). Mining has been one of the main economic activities in Mexico since the XVI Century. At present, it provides the raw material for numerous industries. However, exploitation and processing of ore have produced great amounts of residues that constitute a potential source of heavy metals pollution of the environment (Dudka and Adriano 1997; Armienta Hernández et al. 2001; Armienta et al. 2003). Several environmental threats have been produced by ore extraction and processing in the historical mining zone of Taxco, Guerrero state of Mexico (Armienta Hernández et al. 2000, 2001; Armienta et al. 2003; Romero et al. 2007; Ruiz Huerta and Armienta Hernández 2012; Gómez-Bernal et al. 2014; Tovar-Sánchez et al. 2018). Plant cultivation close to these zones represents a public health problem due to the accumulation 
of heavy metals in the plant organs and their translocation to humans and animals through food chains. Therefore, these topics become important for public health.

Although physicochemical properties of mining wastes vary according to the ore source and processing characteristics, in general, they contain high concentrations of heavy metals such as $\mathrm{Pb}, \mathrm{Ni}, \mathrm{Cd}, \mathrm{Cu}, \mathrm{Mn}$, and $\mathrm{Zn}$ together with low concentrations of essential nutrients like $\mathrm{P}, \mathrm{N}$, and organic matter (Bradshaw et al. 1978; Alloway 1995; Walder and Chavez 1995; Boulet and Larocque 1998). High levels of heavy metals contamination of soils by mining residues have been reported elsewhere (Álvarez et al. 2003; Clemente et al. 2006; Vázquez et al. 2006; Wei et al. 2020).

Heavy metal pollution is a serious environmental problem. Potentially toxic elements ( $\mathrm{Cd}, \mathrm{Cu}, \mathrm{As}$, or $\mathrm{Zn}$ ) settled in the soil may be transferred to the liquid phase depending on physicochemical conditions and become available to plants (Norland and Veith 1995; Wong et al. 1998; De Jesús García et al. 2020). Also, mining wastes produce unfavorable health conditions to native vegetation among other factors through substrate acidification (Wong et al. 1998).

Heavy metals may be toxic to wild vegetation even if their concentration does not reach critical levels. Due to the translocation of metals from root to the aerial parts, they may enter the food chains (Mertens et al. 2004; Unterbrunner et al. 2007; Sharma et al. 2018). Many angiosperm plant species possess adaptations allowing survival and reproduction in $\mathrm{Zn}, \mathrm{Cu}, \mathrm{Pb}, \mathrm{Cd}, \mathrm{Ni}$, and As highly polluted soils (Dahmani-Muller et al. 2000; Pulford and Watson 2003).

In this study, the impact generated by mine tailings on maize (Zea mays) growth was studied. This species was selected as a test plant because it is one of the most common and important cereal crops in Mexico and worldwide. Also, it is considered as a biological, agricultural, cultural and economic patrimony (CONABIO 2006). Maize is an essential component of the Mexican diet and its harvest is an important economic activity for the peasant families. Frequently maize cultivation is located close to mine tailings, but the impact of contaminated soils on plant development is rarely studied even though it represents an important environmental issue with implications on human health along with social consequences (Tovar-Sánchez et al. 2018).

Various experiments have shown heavy metals absorption and accumulation (mainly $\mathrm{Zn}, \mathrm{Cd}, \mathrm{Pb}, \mathrm{Hg}$, and $\mathrm{Cu}$ ) in maize plants (Wójicik and Tukendorf 1999; Kabata-Pendias 2000; Ali et al. 2002; Wenger et al. 2003; Seregin et al. 2004; Seregin and Kozhevnikova 2005; Souza et al. 2005; Wójcik and Tukiendorf 2005; Pál et al. 2006; Shen et al. 2006; Maksimović et al. 2007, Tovar-Sánchez et al. 2018). Uptake and accumulation of high concentrations of heavy metals by a plant not only produce toxic symptoms and affect the metabolic processes, they also causes physiological, developmental, structural, and ultrastructural changes. High concentrations of heavy metals other than $\mathrm{Mn}$ reduce the mesophyll cell size (Zhao et al. 2000), Cd negatively affects chloroplast formation in stem (Barceló et al. 1988), Pb causes a reduction in the number of stomata and trichomes on the abaxial leaf surface caused (Weryszko-Chmielewska and Chwil 2005). Heavy metals induce many other structural and ultrastructural 
changes and among others, they exert genotoxic and cytotoxic effects in plant cells, resulting in cellular, physiological, and morphological alterations (Nagajyoti et al. 2010).

Leaf epidermis (Chardonnens et al. 1998), trichomes on the leaf surface (Salt et al. 1995; Choi et al. 2001; Ager et al. 2002) or epidermal glands (Lavid et al. 2001a, 2001b) are able to detoxify more Cd than the mesophyll cells. Leaf rib and petiole might also be involved in the storage of $\mathrm{Cd}$, as found in knotweed stems (Shinmachi et al. 2003). Shi et al. (2016) found that plants simultaneously exposed to Pb and Cd suffer morphological and physiological abnormalities in absorption and transport of essential elements, chlorophyll synthesis, growth, and reproduction.

Therefore, this study aimed to determine the impact of mine tailings on soil contamination by heavy metals and As and subsequently on maize growth and development. To this end, concentrations of heavy metals and As were determined in plants and soils which were at different distances from mine source, and morpho-anatomical characteristics were evaluated in maize plants grown in these soils under greenhouse conditions. This work will provide an effective evaluation of the impacts from mine tailings exposed to agricultural soils and maize. We present the evidence that in a mining zone even at a substantial distance from a mine site, both substrate and plants grown in it contain high levels of heavy metals and As that affect significantly plant growth and yield.

\section{Materials And Methods}

\section{Sampling location}

Sampling was carried out in the mining zone of Taxco, northern Guerrero State, Mexico. Located between $18^{\circ} 21^{\prime}$ and $18^{\circ} 41^{\prime} \mathrm{N}$ and $99^{\circ} 25^{\prime}$ and $99^{\circ} 47^{\prime} \mathrm{W}$. This zone has a tropical sub-humid climate and an average temperature of $28^{\circ} \mathrm{C}$. Historical precipitation record indicates a yearly average of $1000 \mathrm{~mm}$ (INEGI, 1999). According to FAO/UNESCO (FAO 1977; INEGI 2005), soils are classified as Haplic Phaeozem (IMMSA 1973; COREMI 2013).

\section{Soil sampling and seed material}

Soil samples were collected in Santa Rosa municipality in Guerrero State (Figure 1). Soils were sampled at various distances from the border of mine tailings: agricultural non-polluted soil at about $3000 \mathrm{~m}$ from mine tailings that corresponds to Taxco sample1 (STAX1), agricultural soil at about $400 \mathrm{~m}$ from mine tailings that belongs to Taxco sample2 (STAX2), and soil at about $40 \mathrm{~m}$ from mine tailings that corresponds to Taxco sample3 (STAX3) (Figure 1). Sites STAX1 and STAX2 correspond to agricultural soils used for maize cultivation. At each site, three soil samples of $0-20 \mathrm{~cm}$ soil depth were taken to make a compound sample. The seeds of $\mathrm{H}-515$ Z. mays variety were obtained from plants grown in the region and provided by dwellers. All samples were transported in a container to the Analytical Chemistry Laboratory at the National Autonomous University of Mexico, Mexico City campus.

\section{Greenhouse experimental design}


The seeds were washed with water and surface-sterilized by dipping in $2.5 \% \mathrm{NaOCl}$ for $5 \mathrm{~min}$, and washed 3 times with double-distilled water to remove any traces of chemicals that could interfere with seed germination. The pot experiment was set up in a greenhouse. The pots were $28.3 \mathrm{~cm}$ high with the top diameter of $31 \mathrm{~cm}$ and a bottom diameter of $22 \mathrm{~cm} \mathrm{(15} \mathrm{L).} \mathrm{Each} \mathrm{pot} \mathrm{was} \mathrm{equipped} \mathrm{with} \mathrm{an} \mathrm{outlet} \mathrm{to}$ collect leachates. The pots were arranged in three quintuplet rows in a randomized block design in three tables. Altogether, fifteen pots were filled with soil from each site (STAX1, STAX2, and STAX3), a total of 45 pots, and 5 seeds per pot were sown. The pots were planted/set in January 2009. Maize was grown during 22 weeks in a greenhouse under semi-controlled conditions, where temperature and relative humidity were monitored. Plants grew under natural light and day-night photoperiod and were watered every three days with deionized water avoiding leaching out of the pots. Deionized water was used to avoid possible variability in mineral content of sink water and avoid analytical errors.

\section{Growth conditions in a greenhouse}

The plant height was measured in maize plants weekly for 22 weeks, starting from the second week after the sowing. The maximum temperatures during day hours ranged from 25.6 to $41.5 \mathrm{C}^{\circ}$, and the minimum temperature during the night hours ranged from 12.9 to $15.6 \mathrm{C}^{\circ}$. The average relative humidity was 63.37 $\%(34.25 \%$ to $84.75 \%)$, and the average of solar radiation was $28078 \mathrm{~W} / \mathrm{m}^{2}\left(0.6 \mathrm{~W} / \mathrm{m}^{2}\right.$ to $\left.273.1 \mathrm{~W} / \mathrm{m}^{2}\right)$ (Appendix A of Supplementary data). Harvest time was determined based on the end of the life cycle of maize plants when plants stopped their growth and started to dry.

\section{Morphological characteristics}

Corresponding morphological characteristics were measured in 180 fresh samples (60 per replicate), taken out from plants grown in 45 pots. To obtain the dry weight of each sampled organ, they were dried at $75^{\circ} \mathrm{C}$ until constant weight. The following parameters were collected: fresh and dry weight of aerial parts and the roots, biomass (\%), the longest leaf length $(\mathrm{cm})$, number of leafs. For female reproductive structures, length and dry weight of ears, and dry weight of kernels were recorded as well as percentage of their normal or abnormal appearance. For male reproductive structures, tassel length and number of tassel branches were recorded as well as percentage of their normal or abnormal appearance.

\section{Physicochemical soil analysis}

The soils samples were collected for analysis after the end of the greenhouse experiment. The roots were carefully extracted from each soil sample (STAX1, STAX2, and STAX3). The soil samples were air dried at room temperature and crushed over plastic trays and were sieved through a sieve of $2 \mathrm{~mm}$ mesh size and stored separately for further chemical analyses. Physicochemical parameters: $\mathrm{pH}$, total carbon $(\% \mathrm{C})$, organic matter $(\mathrm{OM})$, total nitrogen $(\mathrm{N})$, available phosphorus $(\mathrm{P})$, electrical conductivity $(\mathrm{EC})$, and cationic exchange capacity (CEC) of soil samples were measured in triplicate.

Carbon and nitrogen analyses were performed with an CHNS Perkin Elmer 2400- II element analyzer (Perkin Elmer, Waltham, MA, USA). Measurement of pH was performed with a potentiometer 3301 set 
WTW in a 1:2.5 soil: liquid ratio (water and $\mathrm{KCl}$ solution/concentration) after $18 \mathrm{~h}$ of agitation. Available $\mathrm{P}$ was determined with a spectrophotometer Genesys 20. Exchangeable bases were analyzed with an AA Perkin-Elmer 3110 after extraction with ammonium acetate at $\mathrm{pH}=7.0$.

\section{Heavy metal and As analysis of soil and plant samples}

For the analysis of total heavy metals and As, soil samples were air dried, homogenized, and sieved through $0.63 \mathrm{~mm}$ mesh size and ground. $1 \mathrm{~g}$ of finely ground soil sample was digested slowly with $20 \mathrm{~mL}$ of aqua regia $\left(1: 3, \mathrm{v} / \mathrm{v}\right.$ : conc. $\mathrm{HNO}_{3}$ and conc. $\left.\mathrm{HCl}\right)$ and digested for $30 \mathrm{~min}$ at $170{ }^{\circ} \mathrm{C}$ using a Microwave Accelerated Reaction System (CEM® MARSXpress). The samples were solubilized and dissolved in deionized water and filtered through Whatman 40; this solution was diluted to a final volume of $100 \mathrm{~mL}$ until analysis. Analysis of $\mathrm{Fe}, \mathrm{Zn}, \mathrm{Cd}, \mathrm{Cu}$, and $\mathrm{Pb}$ was performed by flame atomic absorption spectrometry, and As by hydride generation with a Perkin-Elmer AAnalyst 100 . The instruments were calibrated with standard solutions containing known concentrations of each element. High purity Standard solutions were used for calibration curves. Six replicates were used of each soil sample, accuracy was evaluated with the reference soil NIST Montana soil 2711, obtaining from 83 to $100 \%$ recovery.

Plants were harvested 22 weeks after germination. In total, nine samples (three plants per pot) were analyzed for metal bioaccumulation. All samples were divided into roots, stems, leaves, and ears (cobs) and vigorously washed with deionized water and soaked in ultrasonic bath machine for 20 minutes. Next, plants were dried at $60 \mathrm{C}^{\circ}$ for 4 days until constant weight; each organ sample was cut into small pieces and $0.5 \mathrm{~g}$ were weighed for the extraction of heavy metals and As. These samples were subjected to open acid digestion with $10 \mathrm{ml}$ of acid concentrated mixture $\left(\mathrm{HNO}_{3}\right.$ and $\left.\mathrm{HClO}_{4}, 4: 1\right)$ on a hot plate in a fume hood until appearance of the white fumes indicating complete digestion of plant samples. Then they were cooled, properly filtered, and diluted to a final volume of $50 \mathrm{ml}$ using deionized water and stored in a glass container for further analysis. Thereafter, heavy metal concentrations were measured with an atomic absorption spectrophotometer (Model Perkin-Elmer AAnalyst 100, USA), with flame (Fe, Zn, Cd, and $\mathrm{Cu}$ ), graphite furnace $(\mathrm{Pb})$, and FIAS-HG (As) mode. The detection limits for all the elements are shown in Table 2. For each measurement, the average values of the five replicates were recorded. All metal concentration values are reported as $\mathrm{mg} / \mathrm{kg}$ of dry weight.

\section{Scanning electron microscopy (SEM) analysis}

From each substrate, ten plants were chosen for SEM analyses. Samples from shoot-borne brace roots, stem, and leaves were taken at the same position within each plant. One-centimeter width stem samples were taken from an internode located between phytomers seven and eight. Adaxial and abaxial leaf samples of $1 \mathrm{~cm}^{2}$ were collected from the distal half of leaf seven. For root samples, $1.5-2 \mathrm{~cm}$ long portions of adventitious live and turgescent roots near their base were used. Samples were processed using the conventional SEM protocols (Bozzola and Russell 1999) drying at the critical point with a Samdri 780B dryer. Dry samples were attached to aluminum supports with carbon tape (NEM TAPE 
$8 \mathrm{~mm}$ ) and covered with charcoal and gold in a Bal-Tec SCD 050 sputter coater. Covered samples were observed with a Zeiss JEOL JSM-35CF microscope (applying 15 to $18 \mathrm{kV}$ ) at the Chemistry Faculty, UNAM. Measurements were performed from SEM microphotographs. The computer software package Image Tool V.3 was used for image analysis. On transverse sections of roots and shoots, the diameters of roots and vascular bundles were measured in two directions: the longest (major) diameter and the shortest (minor) diameter.

\section{Statistical analysis}

Statistical analysis was performed on data using SPSS Version 18.0 (SPSS Inc., Chicago, USA). Descriptive analysis was performed for physicochemical parameters and heavy metal and As contents in soil and plant samples studied (in triplicates). For analysis of the morphological characteristics and morpho-structural data, basic statistics, Pearson's correlations and main components were applied.

\section{Results And Discussion}

In this study we analyzed the impact of mine tailings on substrate contamination and plant growth in a range of distances from the mine activity sites. We first analyzed soil samples obtained from about 3000 $\mathrm{m}$ from mine tailings (STAX1), agricultural soil at about $400 \mathrm{~m}$ from mine tailings (STAX2), and soil at about $40 \mathrm{~m}$ from mine tailings (STAX3); the locations are illustrated in Figure 1. After that we addressed accumulation of heavy metals and As in Z. mays plants, and finally evaluated impact of contaminated soils on different aspects of plant growth and development.

\section{Soil physicochemical analyses}

Near neutral pH values (6.9 to 7.5) were found in soils STAX1 and STAX2 while the STAX3 sample was acid $(\mathrm{pH}=4.2) . \mathrm{pH}$ ranges in soil were extremely high and exceeded the soil background according to the criteria proposed by Castellanos et al. (2000) and Mexican accepted regulations, NOM-021-SEMARNAT2000 (SEMARNAT 2000). The soils STAX1 followed by STAX2 were the best suited for plant development; as expected, soil samples STAX3 which were closest to tailings, were least appropriate for plant development. Electric conductivity at STAX1 and 2 showed negligible salinity, whereas STAX3 was moderately saline according to the criteria proposed by NOM-021-SEMARNAT-2000 (SEMARNAT 2000). Organic matter was very high at STAX1, high at STAX2, and medium at STAX3 according to the criteria proposed by NOM-021-SEMARNAT-2000 (SEMARNAT 2000). The level of P was very high at STAX1, low at STAX2 and very low at STAX3, according to the criteria proposed by NOM-021-SEMARNAT-2000 (SEMARNAT 2000); Ca was high at the three sample sites; Mg was medium at STAX1 and STAX2 and very low at STAX3; $K$ was very high at STAX1 and medium at STAX2 and 3 according to the criteria proposed by NOM-021-SEMARNAT-2000 (SEMARNAT 2000). Particularly, the lowest levels of total $C$ and $\mathrm{N}$ and available $\mathrm{P}$ were found in STAX3 soils (see Appendix A of Supplementary data). The most limiting element at this location was P; its level was 62 -fold lower compared to STAX1, whereas total C and N levels were lower only 6-and 3-fold, respectively (See Appendix A of Supplementary data). By applying the 
correlation matrix analysis, significantly negative correlations in physicochemical parameters in soils were found among the used variables (Appendix B of Supplementary data).

\section{Heavy metal and As content in substrates at different distances from mine tailings}

It is important to point out that soils were heavily contaminated by the mining activities and the heavy metal and As contamination showed a decreasing trend with increased distance from mine tailings. As shown in Table 1, the average heavy metal and As contents in soil were distributed as follows Fe> Zn> $\mathrm{Pb}>\mathrm{Cu}>\mathrm{As}>\mathrm{Cd}$. All the studied metals increased in the following way STAX3>STAX1>STAX2 as shown in Table 1. The highest concentrations of contaminant elements were detected in the closest soil to mine tailings (STAX3) and were 3- (Fe), 24- (Zn), 6- (Cu), 8- (Cd), 55- (Pb), and 4 (As) and 9-fold higher at STAX3 compared to STAX2 (Table 1). Concentrations of all the studied elements at STAX3 were above the limits established by US EPA (1992), IHOBE, (2003), and Mexican NOM-147-SEMARNAT/SSA1-2004, and at STAX1 were higher for Cu. Alloway (1995) proposed a limit of $60-125 \mathrm{mg} / \mathrm{kg}$ of $\mathrm{Cu}$ for soils which was exceeded at STAX1 and STAX3 only. European Union's regulatory commission (EU) (2006) sets a limit of $100 \mathrm{mg} / \mathrm{kg}$ of $\mathrm{Cu}$ in soils which was exceeded at STAX1 and STAX3 only. Despite its proximity to mine tailings, metal concentrations were lower in arable land (STAX2) compared to the control site (STAX1), except for Fe and As ( $P>0.05$, Table 1$)$. Various authors found heavy metal concentrations in soils and maize plants were lower at other sites than those measured in this study in the following way: STAX3>STAX1>STAX2 as shown in Table 2 (Oladipo et al. 2016; Bai et al. 2016).

Concentrations of potentially toxic elements at $40 \mathrm{~m}$ from mine tailings (STAX3) detected in our study were within the range of the contents of the same elements reported earlier for Taxco mine tailings, which were for As $=190-800 \mathrm{mg} / \mathrm{kg}, \mathrm{Pb}=378-4932 \mathrm{mg} / \mathrm{kg}, \mathrm{Zn}=58-2949 \mathrm{mg} / \mathrm{kg}$ and $\mathrm{Cu}=25-122 \mathrm{mg} / \mathrm{kg}$ (Romero et al. 2008) (compare with data shown in Table 1), suggesting the fast rate of migration of these elements in the soils.

The significantly positive correlation in soil heavy metal contents was found as follows Fe-S with Cd-Ps, Zn-Pr, Zn-PI, Cd-Pr, Zn-Ps, and Cd-PI (.999, P $\leq 0.05)$; Zn-S with Cd-S, As-S, and Cu-Ps (1, P $\leq 0.01)$; Cd-S with As-S (1, P $\leq 0.01)$, and Cu-Ps (.999, P $\leq 0.05)$; Pb-S with Cd-Ps, Zn-Pr, Zn-PI, Cd-Pr, Zn-Ps, and Cd-PI $(.999, \mathrm{P} \leq 0.05)$ and As-S with Cu-Ps (.999, P $\leq 0.05)$ (Appendix B of Supplementary data). The evidently positive correlations between heavy metals and As in the soils indicated that these elements were probably originated from the same sources and shared the same pathways (Zhang et al. 2018b; Liu et al. 2019d; Zeng et al. 2020).

\section{Heavy Metal and As accumulation in Z. mays}

Application of $\mathrm{Cd}$ and As alone or in combination substantially reduces the plant growth (plant height, number of leaves per plant, leaf area, stem diameter, and shoot fresh and dry weight) (Anjum et al. 2016). Du et al. (2017) and Liu et al. (2009) found that maize plant can be more tolerant under As stress opposite to our study, which shows that maize is not enough tolerant under As stress. Content of As and analyzed metals was highest in roots compared to the aerial parts (stem, leaves, and kernels) (Table 2). 
Higher heavy metals and As contents were found in plants grown in STAX3 substrate compared to more distant sites $(P<0.05)$, while plants grown in STAX1 and STAX2 had values of a similar range $(P>0.05)$

Another research found that maize grown in a greenhouse under semi-controlled conditions showed greater accumulation of $\mathrm{Cd}$ and $\mathrm{Pb}$ in the roots than in the shoots (Figlioli et al. 2019). Besides, Lv et al. (2019), found that maize under moderate toxic metal stress of $\mathrm{Pb}(29.7 \mathrm{mg} / \mathrm{kg}$ in soil) and $\mathrm{Cd}(0.02$ $\mathrm{mg} / \mathrm{kg}$ in soil) showed the following accumulation trend of roots $>$ stems and leaves $>$ grains.

Principal component analysis (PCA) in the organs of the maize (Figure 2) showed that Cu-R (R, in roots), $\mathrm{Pb}-\mathrm{S}$ ( $\mathrm{S}$, in stem), Cu-L ( $\mathrm{L}$, in leaves) Fe-L, and As-R did not have significant relation with the other parameters and Zn-R with Cd-R, Cd-L, Zn-S, Cd-S, and Zn-L; Zn-S with Zn-L, Cd-S, and Cd-L; As-S with Pb-K ( $\mathrm{K}$, in kernels); Fe-K with $\mathrm{Zn}-\mathrm{K}, \mathrm{As}-\mathrm{K}$, and $\mathrm{Cu}-\mathrm{K}$, hence these had significant relation.

\section{Heavy metal and As bioaccumulation in different plant organs}

Roots. Metal and As content was determined only in the adventitious shoot-borne roots developed from the basal stem node; these roots are considered brace roots (Hochholdinger et al. 2004). The highest heavy metal concentrations in roots were found in plants grown in STAX3 soils (Table 2). Interestingly that $\mathrm{Zn}$ and $\mathrm{Pb}$ concentrations in roots were higher in plants grown in STAX1 than in STAX2 while the metal content in the soil was greater in STAX2 (Table 1). This suggests that the lowest concentration of $\mathrm{Zn}$ and $\mathrm{Pb}$ in substrate is less toxic and facilitates the uptake of these elements compared to substrates with the higher metal content. However, Fe and As concentrations were higher in roots of STAX2 than STAX1. The observed trend reflects a relationship between the substrate and the amount of metal absorbed by the plants causing inhibition of root growth by heavy metal. These data are in good agreement with barrier function of plant roots (De-Jesús-García et al. 2020). The significant positive correlation of heavy metal content in roots was found as follows Fe-R with Fe-S (.998, P $\leq 0.05)$, and As-L (.997, P $\leq 0.05)$; Zn-R with Cd-R, Cd-L, Zn-S, Cd-S, and Zn-L (1, P $\leq 0.01)$; Cu-R with As-S and Pb-K (-.998, P $\leq 0.01$ ) (Appendix B of Supplementary data).

Stem. Similarly, to roots, the highest metal content was found in stems of pants grown in STAX3, except for $\mathrm{Pb}$ and As (Table 2) The As concentration was the same in plants grown in STAX1 and STAX3 but greater in STAX2. Interestingly, the level of $\mathrm{Zn}, \mathrm{Cu}$, and $\mathrm{Cd}$, in stems was found to be the same in plants grown in STAX1 and STAX2, suggesting low root to shoot translocation of these elements. However, in STAX3, the content of $\mathrm{Zn}$ in stems increased 28-fold for $\mathrm{Zn}$ and only 2- and 7-fold for $\mathrm{Cu}$ and $\mathrm{Cd}$, respectively, compared to plants grown in STAX1 (Table 2) The only element whose content was progressively increased with a decreased distance to mine tailings was Fe (Table 2). The Pb content in stem samples was surprisingly similar in plants grown in STAX1 and STAX3. stems. Output of the correlation analysis showed significantly higher positive correlation in content of Fe-S with As-L (1,

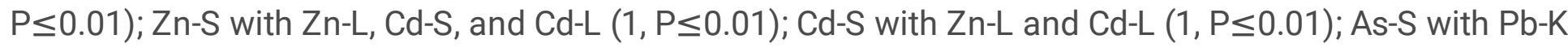
(1, P $\leq 0.01) ; Z n-L$ with Cd-L (1, P $\leq 0.01)$ (Appendix B of Supplementary data). This analysis showed that barrier function of pant roots (De-Jesús-García et al. 2020) is efficient to a different degree for different elements and at different soil contamination levels. Close to mine tailings, the plants can contain rather 
high levels of Fe and $\mathrm{Zn}$ and moderate levels of $\mathrm{Cu}$ and $\mathrm{Cd}$, therefore a plant forage could be harmful for animal consumption.

Leaves. Results showed that Fe, Zn, Cd, and As concentrations in leaves were higher in STAX3 samples than STAX1 and STAX2, except for $\mathrm{Cu}$ and Pb presenting a higher or the same content in STAX1, respectively (Table 2). Interestingly, for $\mathrm{Zn}$ and $\mathrm{Cd}$ the content in leaves was the same in the samples of STAX1 and STAX2. However, overall analysis showed that accumulation was at maximum for $\mathrm{Zn}$, and Cd in STAX3 their content was 6- and 2-fold greater than in STAX1 samples, respectively (Table 2). Some authors reported that heavy metal concentrations affect the structure of the leaves in different ways. Navarro-Pedreño et al. (2003) found that heavy metal content affects preferentially younger leaves than mature leaves. Also, Sharma et al. 2003 found that toxic elements in Z. mays causes visible lesions such as chlorosis, vein clearing in young leaves, curling of leaf margin, and yellowing.

Kernels. The content of heavy metals and As in maize kernels ranged from 26.2 to $30.5 \mathrm{mg} / \mathrm{kg}$ for Fe, from 29.0 to $41.9 \mathrm{mg} / \mathrm{kg}$ for $\mathrm{Zn}$, from 2.8 to $5.2 \mathrm{mg} / \mathrm{kg}$ for $\mathrm{Cu}$, from 0.5 to $1.4 \mathrm{mg} / \mathrm{kg}$ for Cd, from 0.5 to $0.6 \mathrm{mg} / \mathrm{kg}$ for $\mathrm{Pb}$, and 0.0 to $0.2 \mathrm{mg} / \mathrm{kg}$ for As and no higher level of either metals or As in STAX3 samples compared to STAX 1 was found (Table 2). Unexpectedly, the highest metal content was detected in kernels of plants grown in soils from STAX1 and it was 18,30, and $56 \%$ higher for $\mathrm{Zn}, \mathrm{Cu}$, and $\mathrm{Cd}$ compared to STAX3 samples (Table 2). These results further confirmed that maize grains at sampling sites were heavily contaminated and these contents may cause health risks to consumers. Barać et al. (2016) found that maize kernel heavy metal concentrations vary depending on growth location (Nigeria, USA, Sweden, and Kosovo). However, the reported metal contents are lower than in this study.

Importantly, As and some metal contents detected at different sites in our study were within the range detected in sweet maize kernels produced by plants grown in natural non-contaminated soils (KabataPendias 2000), whose concentration ranges for Cu were from 1.4 to $2.1 \mathrm{mg} / \mathrm{kg}, \mathrm{Zn}$ from 25 to $36 \mathrm{mg} / \mathrm{kg}$, As from 0.03 to $0.4 \mathrm{mg} / \mathrm{kg}$, and $\mathrm{Pb}$ from 0.3 to $3.0 \mathrm{mg} / \mathrm{kg}$ (Table 3). Our study thus demonstrates that despite seriously contaminated soils and a high level of accumulation of heavy metals and As in vegetative organs, kernels accumulated the contaminants to a very limited extent even in the most contaminated soil samples of STAX3.

Alamgir et al. (2016) found that in the aerial part of maize plant the maximum content of $\mathrm{Cu}$ was 0.29 $\mathrm{mg} / \mathrm{kg}$ of dry weight, and of $\mathrm{Pb}$ was $5.8 \mathrm{mg} / \mathrm{kg}$. These values were similar to those obtained in our study; for $\mathrm{Cu}$; it was on average $0.21 \mathrm{mg} / \mathrm{kg}$, and for $\mathrm{Pb} 5.34 \mathrm{mg} / \mathrm{kg}$. In this study, highly significant and positive

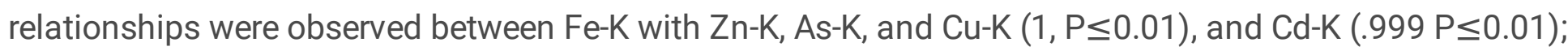

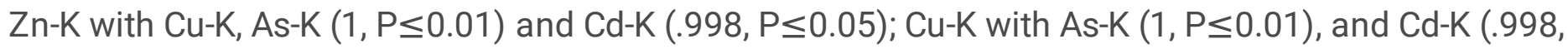
$P \leq 0.01)$; Cd-K with As-K (.998, P $\leq 0.01)$ (Appendix B of Supplementary data). Overall, analysis of heavy metals and As contents in plants grown in contaminated soils showed the highest level of elements in roots is followed, for the majority of elements, by those in leaves, stems and kernels. These results clearly indicate that consumption of maize plants as forage by animals even at sites as far as $3 \mathrm{~km}$ from a 
mining site can represent a danger and the elements consumed could be transferred to the food chain to humans.

\section{Plant Growth and Development}

To better understand plant growth and developmental abnormalities, some growth parameters and developmental aspects of plants grown in the three soil samples were analyzed. The timing of seed germination in soils was recorded. The seed germination started at 3 or 4 days after the sowing and was completed by 15 days. The germination time differences could be related to slight differences in soil depth where the seeds were imbibed. For a total of 225 maize seeds ( 5 seeds per pot) planted, a 95\% germination was observed irrespectively of soil types. After germination of most plants and seedlings emerged, 30 plants were extracted, 10 from each substrate, to determine wet and dry weights and size.

In plants of 20 days of growth no differences were found among plants grown in different substrates. The average length of the aerial part ranged from 8 to $12 \mathrm{~cm}$, fresh weight was $1 \mathrm{~g}$ for seedlings grown in all substrates, and dry weight was from 0.28 to $0.32 \mathrm{~g}$. All plants (from STAX1, STAX2, and STAX3) by this time developed 3 leaves. The 20-day seedlings did not show any morphological signs of abnormal development. However, after 20 days of growth, maize plantlets were more vigorous when grown in the STAX1 substrates, the most remote of the tailings, followed by STAX2 and STAX3. Plants grown in STAX3 soil showed visual symptoms of toxicity such as retarded growth, thin leaves with necrosis, chlorosis and brown hues. These effects were among other factors due to the high concentrations of heavy metals (Table 1) causing phytotoxic effects and were similar to the reported cases (Lagriffoul et al. 1998; Souza and Rauser 2003; Souza et al. 2005).

Maize plants grown at STAX1 soils at about 22 weeks reached a height of an average of $132 \mathrm{~cm}$ and were healthy, while those grown in substrate STAX2 were $86 \mathrm{~cm}$ and in STAX3 $64 \mathrm{~cm}$ of height (Figure 3). Also, a certain degree of plant stress was observed as plant leaves were yellowish and reddish. The observed plant height trend was STAX1>STAX2>STAX3. This corresponded well with decreased distancedependent negative impact of contamination from mine tailing soils. As by 20 days there were no differences in the shoot length among plants grown in different substrates, these differences at the end of experiment also reflected changes in relative growth rate under these conditions.

Metal accumulation varies depending on the plant developmental stage as shown for 30 and 70 day maize plants (Ruiz and Armienta 2012). It is known that heavy metals affect significantly plant growth in maize, including roots, leaves, cobs, and stems (Wei et al. 2020; Anjhum et al. 2016; Tovar et al. 2018). Additionally, Ruiz and Armienta, (2012) and Drlickova et al. (2013) found that As is also harmful for maize growth. This indicates that the effects on the maize plant are manifested at an early stage, however, it is important to highlight the ability of these species to withstand high concentrations of potentially toxic metals, complete their physiological cycle and reach the reproductive developmental stage and form ears and tassels.

\section{Morphological and physiological characteristics of $Z$. mays grown in contaminated soils}


After 22 days of growth, plants grown in STAX2 and STAX3 soils showed the greatest structural and morphological visible changes. As shown in Figure 4, differences in leaf maximum length were found in plants grown in the studied soil substrates $(73 \mathrm{~cm}, 42 \mathrm{~cm}$, and $25 \mathrm{~cm}$, for STAX1, STAX2, and STAX3, respectively, Table 3).

Plant growth was significantly affected in plants grown in STAX2 and STAX3 substrates compared to those in STAX1. The fresh weight of aerial part of plants grown in STAX2 and STAX3 was 5- and 12-fold reduced compared to that in STAX1 $(P<0.05$, Table 3$)$. Plants grown in STAX3 soils presented the greatest developmental problems, while plants grown in STAX1 soil, far from the mining wastes, were healthy and had developed on average 13 phytomers (Table 3 ). Average number of phytomers developed by the end of experiment was also progressively diminished (10 at STAX2, and 8 at STAX3, $P<0.05$ ) (Table 3), suggesting that the activity of shoot apical meristem was severely compromised when plants grew in presence of heavy metal and As contaminated soils. Similarly, a progressive decrease in root fresh weight was found in increasingly contaminated soils (Table 3).

Despite severe growth abnormalities, maize plants grown in contaminated substrates reached the reproductive stage and formed male (spikes) and female (ears) inflorescences, however, clear differences in their development and size were observed (Figure 5, Table 4). Ear weight was following the trend STAX1>STAX2>STAX3. Abnormalities in the reproductive organ development in plants grown in soils STAX2 and STAX3 were detected in 54 and $72 \%$ (ear), and 48 and 92\% (tassel) of plants, respectively. Despite this abnormal development, in plants grown in the soil closest to mine tailings (STAX3), ears were only $20 \%$ shorter than in plants grown in STAX1 and STAX2 soils $(P<0.05$, Table 3$)$. The ear dry weight was progressively diminished in plants grown in STAX2 and STAX3 compared to those grown in STAX1 (Table 3). Differences in the general plant and ear appearance, including stem pigmentation, in 22-week plants grown in the soils tested are shown in Figure 4.

Kernel formation was also affected in maize plants grown in contaminated soils. Kernels harvested from STAX1 plants weighed $0.18 \mathrm{~g}$, from STAX2, $0.11 \mathrm{~g}$, and STAX3, $0.06 \mathrm{~g}$ and no differences were found among STAX2 and STAX3 samples (Table 3). This suggests that even intermediate level of contamination has a strong effect on ear and kernel development.

Tassel development, particularly their growth in length, was progressively and significantly diminished with the following trend STAX1>STAX2>STAX3 (Table 3). Similarly, their branching was significantly affected: in STAX3 plants no branching was present while in plants grown in STAX1 soils 5 branches on average were formed (Table 3). Furthermore, a fusion of the reproductive structures (tassel joint with ear) in STAX3 were also found and reflected developmental alterations in maize plants grown in this substrate (Figure 4). These results clearly indicate that heavy metal content influenced the morphogenesis and development of reproductive organs. The detected abnormalities can be used as easily detectable symptoms for the assessment of the negative impact of mining wastes in maize plants grown nearby and are related to a high level of heavy metals and As in mining-impacted soils. 
In this study, it was evidenced that maize plants are capable to complete all development stages, including generative development and seed formation. Our results are also consistent with other studies of maize influenced by heavy metals and As where the authors refer to developmental changes in maize plant. For example, Tovar-Sánchez et al. (2018) found altered micromorphology in younger leaves of $Z$. mays samples from polluted sites; Anjhum et al. (2017) found that application of $\mathrm{Cd}$ and As was detrimental for morpho-physiological features and yield performance of maize cultivars; Ruiz-Huerta et al. (2017) reported that the bioaccumulation of As in maize is determined by the ratio of As in roots over the total As in soil. Therefore, our results show that $Z$. mays is a species with a great capacity and resistance to grow in hostile environments, particularly in substrates that contain high heavy metals and As contents.

Application of heavy metals and As in combination substantially reduced maize growth (plant height, number of leaves per plant, leaf area, stem diameter, and shoot fresh and dry weight). These results are consistent with those reported earlier (Nagajyoti et al. 2010; Xu and Shi 2000) Significant morphological and physiological differences were observed among plants grown in soils with different As and heavy metal contents. Although studies have been developed on metal absorption by maize, few ones have been performed with adult plants (Shi et al. 2016). Results showed high contaminants absorption and a significant decrease in physiologic and metabolic rate, decreasing the biomass and producing abnormalities in the fertilization or reproduction stage. Reported morphological changes in maize plants include chlorosis, necrosis in young leaves, decrease in the number of leaves, and roots and brown appearance in roots (Kabata-Pendias 2000). Plant height and leaf area are reduced when plants are exposed to $\mathrm{Pb}$ and $\mathrm{Cd}$ in many plant species (Gopal and Rizvi 2008).

Significant morphological and physiological differences were observed among plants grown in soils with different As and heavy metal contents. Wei et al. (2020) found that most of the metals, such as Pb, Zn, Cr, and $\mathrm{Mn}$, were mainly accumulated in the roots. Results show that in general, individuals exposed to multimetal contaminated soils were smaller, had altered leaf shape structures, and altered micromorphological characters (Ruiz-Huerta et al. 2017; Tovar-Sánchez et al. 2018; Kabata-Pendias 2000). All these data are consistent with the results obtained in this study. In addition, our study suggests that the combined effect of simultaneous exposure to different heavy metals and As has a strong synergic effect, as the developmental and morphological alteration in plant development seem to be more severe than those reported in the literature when treated with individual contaminated agents.

\section{Contaminated soils impact in Z. mays development at the structural level}

\section{Morphometric and qualitative changes in roots}

Adventitious roots were analyzed near their connection with the stem. At this level, roots had epidermal layer followed by 5-7 cortical cell layers and by endodermis. Inside to the endodermis, a central (vascular) cylinder is recognized as it is shown in figure 5 (1a-1c). Plants grown in STAX3 had the thinnest roots and the root cells were of the smallest diameter compared to those in plants grown in STAX1 and STAX2. Besides, STAX3 roots showed other alterations, a decrease in the central cylinder diameter and the 
thickness of cortex (Figure 5 and Table 4). All the measured root parameters: root diameter, central cylinder diameter and the number of metaxylem sectors followed the same pattern and the values were significantly and progressively diminished from STAX1 to STAX2 to STAX3 samples (Table 4). It is known that in field-grown maize, lateral root diameter at the base positively correlates with total root length (Wu et al. 2016). It seems that the same may hold for the studied here adventitious roots. In agreement with this a clear correlation is found between a significantly diminished root biomass (Table 3 ) and a decreased root diameter and the number of metaxylem sectors (Table 4) in plants grown in STAX2 and STAX3 soils compared to STAX1.

\section{Morphometric and qualitative changes in stems}

Similarly to roots, stem diameter was progressively diminished from STAX to STAX3 samples.

Deformation of the stem due to the pressure of developing wrapping leaves was also observed (Figure 5). In plant grown in STAX2 and STAX3 soils, the number of vascular bundles and average parenchyma stem cell diameter was significantly diminished and was 63 and $45 \%$ of STAX1 (for bundles) and 73 and $33 \%$ of STAX1 (for cell diameter). Despite that cell diameter in STAX3 stems decreased 3-fold compared to STAX1, cell density (number of cells per stem area) increased in STAX3 only 2.1-fold (Table 4), suggesting that cell production by the shoot apical meristem was significantly affected in the plants grown in contaminated soils.

\section{Morphometric and qualitative changes in leaves}

Analyzing abaxial and adaxial leaf surface in plants grown in STAX2 and STAX3 soils, no clear differences were found compared to STAX1 samples (Figure 5). Maize leaves in plants grown in STAX1 and STAX2 soils, had normal appearance of macro-trichomes, micro-trichomes, glandular trichomes, stomata on their epidermis. In samples growing in STAX3 souls cutin plugs (CP) were present. This corresponds to the decreased leaf length in STAX3 samples compared to the other samples (Table 4).

Analysis of leaf surface showed no decrease in the number of stomata in plants grown in contaminated soils and only epidermis pavement cell length was affected in STAX3 samples which were $77 \%$ of that in STAX1 (Table 4). Considering that leaf length in STAX3 decreased 2.9-fold in STAX3 compared to STAX 1 (Table 3) but cell length was diminished less than 2-fold, the data suggest that the number of cells and thus cell proliferation during leaf development was strongly affected in plants grown in contaminated soil. Overall this analysis shows that both vegetative and generative maize organs are negatively affected by mining impacted soils through a number of developmental abnormalities and negative effects on cell production and cell growth.

\section{Conclusions}

In this study we showed that the mining activity strongly affects the level of contamination of nearby soils and the highest contamination levels were found at STAX3 site, except for As which was the greatest in STAX2 soil. This contamination affected strongly both vegetative and generative organ 
development which was a consequence of bioaccumulation of metals and As in plant organs, which were in most cases the greatest in plants grown at the closes to mine tailings. Plants grown in STAX2 and STAX3 were negatively affected compared to those in STAX3 in a number of developmental aspects, most significantly their height, phytomer number, reproductive structures (tassel and ear), leaf and root growth, stem diamantes and biomass.

Maize may tolerate and grow in soils with high-heavy metals concentrations without interrupting its biological life cycle and reach the reproductive stage. This is consistent with the fact that in the maize genome a number of metal-detoxifying genes have been identified (Vielle-Calzada et al., 2009). However, development of various organs in plants grown close to mining-site-impacted soils was affected, as data suggest, mainly through inhibition of cell production and cell growth resulted in developmental and growth abnormalities. Morphological characteristics of reproductive structures (tassel, ear, and kernel) may be important factors for visual identification of damage from mining influence. Morphometric analysis showed the soil contamination affects plant development depending on their closeness to the mining residues. These effects are reflected in the size and density of some structures in tissues, as well as cell morphology such as the number of metaxylem sectors by area, the abundance of the vascular bundle and others. Morphological alterations are clear to the naked eye and they may be used as a marker of plant damage from the stress caused by mining-impacted soils.

\section{Declarations}

\section{Acknowledgments}

The authors appreciate the doctoral fellowship of Consejo Nacional de Ciencia y Tecnología (CONACyT) and the Posgrado en Ciencias de la Tierra, Universidad Nacional Autónoma de México (UNAM) for Esther Aurora Ruiz-Huerta. Authors thank Nora Ceniceros, Alejandra Aguayo, and Olivia Cruz for their skillful collaboration in analytical determinations and Guillermina González Mancera for help with scanning electron microscopy. The work in Joseph G. Dubrovsky laboratory is supported by CONACyT (grant A1-S9236) and Programa de Apoyo a Proyectos de Investigación e Innovación Tecnológica-UNAM (grants IN200818 and IN204221).

Funding. The authors appreciate the doctoral fellowship of Consejo Nacional de Ciencia y Tecnología (CONACYT) and the Posgrado en Ciencias de la Tierra, Universidad Nacional Autónoma de México (UNAM) for Esther Aurora Ruiz-Huerta. The work in Joseph G. Dubrovsky laboratory is supported by CONACyT (grant A1-S-9236) and Programa de Apoyo a Proyectos de Investigación e Innovación Tecnológica-UNAM (grants IN200818 and IN204221).

Conflicts of interest/Competing interests. The authors declare that they have no known competing financial interests or personal relationships that could have appeared to influence the work reported in this paper.

Availability of data and material. Not applicable 
Code availability. Not applicable

Authors' contributions. Conceptualization, Esther A. Ruiz-Huerta, Juan M. Gómez-Bernal and María A. Armienta-Hernández; Formal data analysis, Esther A. Ruiz-Huerta, María A. Armienta-Hernández, Juan M. Gómez-Bernal and Joseph G. Dubrovsky; Project administration, Esther A. Ruiz-Huerta and María A. Armienta-Hernández; Writing-original draft; Esther A. Ruiz-Huerta, Juan M. Gómez-Bernal, and Joseph G. Dubrovsky; Writing-review \& editing, Esther A. Ruiz-Huerta, Juan M. Gómez-Bernal, María A. ArmientaHernández and Joseph G. Dubrovsky.

Ethics approval. Not applicable

Consent to participate. Not applicable

Consent for publication. Not applicable

\section{Supplementary data to this article can be found online at}

\section{References}

1. Adamo P, Dudka S, Wilson MJ, McHardy WJ (2002) Distribution of Trace Elements in Soils from the Sudbury Smelting Area (Ontario, Canada). Water Air Soil Pollut 137:95-116. https://doi.org/10.1023/A:1015587030426

2. Adriano DC (2001) Trace Elements in Terrestrial Environments. Springer New York, New York, pp 6189

3. Ager FJ, Ynsa MD, Domınguez-Solıs JR, Gotor C, Respaldiza MA, Romero LC (2002) Cadmium localization and quantification in the plant Arabidopsis thaliana using micro-PIXE. Nuclear Instruments and Methods. Physics Research Section B: Beam Interactions with Materials Atoms 189(1-4):494-498. https://doi.org/10.1016/S0168-583X(01)01130-2

4. Alamgir A, Khan MA, Shaukat SS, Shahab S, Mahmood K (2016) Estimation of Environmental Pollutants in Vegetables. Int J Veg Sci 22(2):161-169. https://doi.org/10.1080/19315260.2014.984263

5. Alharbi NS, Hu B, Hayat T, Rabah SO, Alsaedi A, Zhuang L, Wang X (2020) Efficient elimination of environmental pollutants through sorption-reduction and photocatalytic degradation using nanomaterials. Front Chem Sci Eng 1-12. https://doi.org/10.1007/s11705-020-1923-z

6. Ali NA, Bernal MP, Ater M (2002) Tolerance and bioaccumulation of copper in Phragmites australis and Zea mays. Plant Soil 239:103-111. https://doi.org/10.1023/A:1014995321560

7. Alloway BJ (1995) Heavy Metals in Soils, Springer. Netherlands http://dx. doi. org/10.1007/978-94007-4470-7

8. Ali H, Khan E, Sajad MA (2013) Phytoremediation of heavy metals concepts and applications. Chemosphere 91(7):869-881. https://doi.org/10.1016/j.chemosphere.2013.01.075 
9. Alloway BJ (1995) Soil processes and the behaviour of heavy metals. In: Heavy Metals in Soils (Alloway B. Chapman \& Hill, J., ed.). London

10. Alvarez E, Marcos MF, Vaamonde C, Fernández-Sanjurjo MJ (2003) Heavy metals in the dump of an abandoned mine in Galicia (NW Spain) and in the spontaneously occurring vegetation. Sci Total Environ 313(1-3):185-197. https://doi.org/10.1016/S0048-9697(03)00261-4

11. Anjum SA, Tanveer M, Hussain S, Ashraf U, Khan I, Wang L (2017) Alteration in growth, leaf gas exchange, and photosynthetic pigments of maize plants under combined cadmium and arsenic stress. Water Air Soil Pollut 228(1):13. https://doi.org/10.1007/s11270-016-3187-2

12. Armienta Hernández MA, Talavera O, Ceniceros N, Aguayo A, Cruz O (2000) Caracterización geoquímica de cuerpos de agua en la zona Taxco - Taxco El Viejo Gro. Actas INAGEQ

13. Armienta Hernández MA, Talavera $\mathrm{O}$, Barrera M, Morton $\mathrm{O}$, Villaseñor G, Cruz $\mathrm{O}$, Ceniceros N, Aguayo A (2001) Movilidad de metales pesados a partir de jales en Taxco Gro. Actas INAGED

14. Armienta MA, Talavera O, Morton O, Barrera M (2003) Geochemistry of Metals from Mine Tailings in Taxco, Mexico. Bull Environ Contam Toxicol 71:0387-0393. DOI:10.loo7/soo128-0o3-0176-0

15. Bai YC, Zuo WG, Zhao HT, Mei LJ, Gu CH, Guan YX, Wang XK, Gu MJ, Zang KY, Shan YH, Feng K (2017) Distribution of heavy metals in maize and mudflat saline soil amended by sewage sludge. $J$ Soils Sediments 17(6):1565-1578. https://doi.org/10.1007/s11368-016-1630-z

16. Barać N, Škrivanj S, Mutić J, Manojlović D, Bukumirić Z, Živojinović D, Petrović R, Ćorac A (2016) Heavy metals fractionation in agricultural soils of $\mathrm{Pb} / \mathrm{Zn}$ mining region and their transfer to selected vegetables. Water Air Soil Pollut 227(12):481. https://doi.org/10.1007/s11270-016-3177-4

17. Barceló J, Vázquez MD, Poschenrieder C (1988) Cadmium-Induced Structural and Ultrastructural Changes in the Vascular System of Bush Bean Stems. Bot Acta 101:254-261. https://doi.org/10.1111/j.1438-8677.1988.tb00041.x

18. Beltrano J, Gimenez DO (2015) Cultivo en hidroponía. Editorial de la Universidad Nacional de La Plata (EDULP)

19. Bostick BC, Sun J, Landis JD, Clausen JL (2018) Tungsten speciation and solubility in munitionsimpacted soils. Environ Sci Technol 52(3):1045-1053. https://doi.org/10.1021/acs.est.7b05406

20. Boulet MP, Larocque ACL (1998) A comparative mineralogical and geochemical study of sulfide mine tailings at two sites in New Mexico, USA. Environ Geol 33:130-142. https://doi.org/10.1007/s002540050233

21. Bozzola JJ, Russell LD (1999) Electron Microscopy: Principles and Techniques for Biologists. Jones \& Bartlett Learning

22. Bradshaw AD, Humphreys MO, Johnson MS (1978) The value of heavy metal tolerance in the revegetation of metalliferous mine wastes. Environ Manag Miner Wastes Sijthoff Noordhoff Neth 311-314

23. Castellanos JZ, Uvalle-Bueno JX, Aguilar-Santelises A (2000) Manual de interpretación de análisis de suelos y aguas. Instituto de Capacitación para la Productividad Agrícola 
24. Chardonnens AN, Ten Bookum WM, Kuijper LDJ, Verkleij JAC, Ernst WHO (1998) Distribution of cadmium in leaves of cadmium tolerant and sensitive ecotypes of Silene vulgaris. Physiol Plant 104:75-80. https://doi.org/10.1034/j.1399-3054.1998.1040110.x

25. Chen R, Chen H, Song L, Yao Z, Meng F, Teng Y (2019) Characterization and source apportionment of heavy metals in the sediments of Lake Tai (China) and its surrounding soils. Sci Total Environ 694:133819. https://doi.org/10.1016/j.scitotenv.2019.133819

26. Choi YE, Harada E, Wada M, Tsuboi H, Morita Y, Kusano T, Sano H (2001) Detoxification of cadmium in tobacco plants: formation and active excretion of crystals containing cadmium and calcium through trichomes. Planta 213(1):45-50. https://doi.org/10.1007/s004250000487

27. Clemente R, Almela C, Bernal MP (2006) A remediation strategy based on active phytoremediation followed by natural attenuation in a soil contaminated by pyrite waste. Environ Pollut 143:397-406. https://doi.org/10.1016/j.envpol.2005.12.011

28. CONABIO (Comisión Nacional para el Conocimiento y uso de la Biodiversidad), 2006. Natural capital and social welfare. CONABIO, Mexico

29. COREMI (2013) Monografía Geológico Minera del Estado de Guerrero. Servicio Geológico Mexicano

30. Cuevas G, Walter I (2004) Metales pesados en maíz (Zea mays L.) cultivado en un suelo enmendado con diferentes dosis de compost de lodo residual. Rev Int de Contam Ambient 20(2):59-68

31. Cunningham LM, Collins FW, Hutchinson TC (1975) Physiological and biochemical aspects of cadmium toxicity in soybean. I. Toxicity symptoms and autoradiographic distribution of $\mathrm{Cd}$ in roots, stems and leaves, in: Symposium Proceedings of the International Conference on Heavy Metals in the Environment. pp. 97-120

32. Dahmani-Muller H, van Oort F, Gélie B, Balabane M (2000) Strategies of heavy metal uptake by three plant species growing near a metal smelter. Environ Pollut 109:231-238.

https://doi.org/10.1016/S0269-7491(99)00262-6

33. De-Jesús-García R, Rosas U, Dubrovsky JG (2020) The barrier function of plant roots: biological bases for selective uptake and avoidance of soil compounds. Funct Plant Biol 47(5):383-397. https://doi.org/10.1071/FP19144

34. Dragović S, Mihailović N, Gajić B (2008) Heavy metals in soils: distribution, relationship with soil characteristics and radionuclides and multivariate assessment of contamination sources. Chemosphere 72(3):491-495. https://doi.org/10.1016/j.chemosphere.2008.02.063

35. Dudka S, Adriano DC (1997) Environmental Impacts of Metal Ore Mining and Processing: A Review. J Env Qual 26:590-602. https://doi.org/10.2134/jeq1997.00472425002600030003x

36. Du L, Xia X, Lan X, Liu M, Zhao L, Zhang P, Wu Y (2017) Influence of arsenic stress on physiological, biochemical, and morphological characteristics in seedlings of two cultivars of maize (Zea mays L.). Water Air Soil Pollut 228(2):55. https://doi.org/10.1007/s11270-016-3231-2

37. Fässler E, Robinson BH, Stauffer W, Gupta SK, Papritz A, Schulin R (2010) Phytomanagement of metal-contaminated agricultural land using sunflower, maize and tobacco. Agric Ecosyst Environ 136(1-2):49-58. https://doi.org/10.1016/j.agee.2009.11.007 
38. FAO (1977) Guía para la descripción de perfiles de suelo. Food Agric. Organ. U. N. Available at http://www.fao.org/publications/card/es/c/0f070cdd-1b6d-53fa-add1-5c972fb299d2. Accessed on 19th April 2015

39. Freeling M, Walbot W (1994) The maize handbook. Springer-Verlag, New York

40. Gómez-Bernal JM, Morton-Bermea O, Ruiz-Huerta EA, Armienta-Hernández MA, Dávila González 0 (2014) Microscopic evidences of heavy metals distribution and anatomic alterations in breachingleaves of Cupressus lindleyi growing around mining wastes. Microsc Res Tech 77:714-726. https://doi.org/10.1002/jemt.22392

41. Henriques FS, Fernandes J (1991) Metal uptake and distribution in rush (Juncus conglomeratus L.) plants growing in pyrites mine tailings at Lousal. Portugal Sci Total Environ 102:253-260. https://doi.org/10.1016/0048-9697(91)90319-A

42. Hochholdinger F, Park WJ, Sauer M, Woll K (2004) From weeds to crops: genetic analysis of root development in cereals. Trends Plant Sci 9(1):42-48. https://doi.org/10.1016/j.tplants.2003.11.003

43. Hu B, Ai Y, Jin J, Hayat T, Alsaedi A, Zhuang L, Wang X (2020) Efficient elimination of organic and inorganic pollutants by biochar and biochar-based materials. Biochar, pp 1-18. https://doi.org/10.1007/s42773-020-00044-4

44. IHOBE SP de G.A (2003) Manual práctico para la investigación de la contaminación del suelo. Propues. Plan Dir. Para Protección Suelo Dep. Urban. Vivienda Medio Ambiente Gob. Vasco 1

45. IMMSA (1973) Yacimientos minerales metálicos del Distrito Minero de Taxco (Reporte Interno, Taxco, Guerrero-México). Industrial Minera México S.A

46. INEGI (2005) Prontuario de información geográfica municipal de los Estados Unidos Mexicanos. Taxco de Alarcón, Guerrero. Instituto Nacional de Estadística y Geografía de México

47. INEGI (1999) Síntesis geográfica del Estado de Guerrero. Instituto Nacional de Estadística, Geografía e Informática, Aguascalientes, México

48. Kabata-Pendias A (2000) Trace Elements in Soils and Plants, Third Edition. CRC Press

49. Lagriffoul A, Mocquot B, Mench M, Vangronsveld J (1998) Cadmium toxicity effects on growth, mineral and chlorophyll contents, and activities of stress related enzymes in young maize plants (Zea mays L.). Plant Soil 200:241-250. https://doi.org/10.1023/A:1004346905592

50. Lavid N, Barkay Z, Tel-Or E (2001a) Accumulation of heavy metals in epidermal glands of the waterlily (Nymphaeaceae). Planta 212:313-322. https://doi.org/10.1007/s004250000399

51. Lavid N, Schwartz A, Lewinsohn E, Tel-Or E (2001b) Phenols and phenol oxidases are involved in cadmium accumulation in the water plants Nymphoides peltata (Menyanthaceae) and Nymphaeae (Nymphaeaceae). Planta 214:189-195. https://doi.org/10.1007/s004250100610

52. Lin W, Xiao T, Wu Y, Ao Z, Ning Z (2012) Hyperaccumulation of zinc by Corydalis davidii in Znpolluted soils. Chemosphere 86:837-842. https://doi.org/10.1016/j.chemosphere.2011.10.060

53. Liu WT, Zhou QX, Sun YB, Liu R (2009) Variety difference of lead accumulation and translocation in Chinese cabbage (Brassica peckinensis L.). J Environ Sci (China) 29(1):63-67 
54. Liu J, Wei X, Zhou Y, Tsang DC, Yin M, Lippold H, Yuana W, Wang J, Feng Y, Chen D (2020a) Thallium contamination, health risk assessment and source apportionment in common vegetables. Sci Total Environ 703:135547. https://doi.org/10.1016/j.scitotenv.2019.135547

55. Lv J (2019) Multivariate receptor models and robust geostatistics to estimate source apportionment of heavy metals in soils. Environ Pollut 244:72-83. https://doi.org/10.1016/j.envpol.2018.09.147

56. Maksimović I, Kastori R, Krstić L, Luković J (2007) Steady presence of cadmium and nickel affects root anatomy, accumulation and distribution of essential ions in maize seedlings. Biol Plant 51:589592. https://doi.org/10.1007/s10535-007-0129-2

57. Mantovi P, Bonazzi G, Maestri E, Marmiroli N (2003) Accumulation of copper and zinc from liquid manure in agricultural soils and crop plants. Plant Soil 250:249-257.

https://doi.org/10.1023/A:1022848131043

58. Mertens J, Vervaeke P, Schrijver AD, Luyssaert S (2004) Metal uptake by young trees from dredged brackish sediment: limitations and possibilities for phytoextraction and phytostabilisation. Sci Total Environ 326:209-215. https://doi.org/10.1016/j.scitotenv.2003.12.010

59. Morel J-L (1997) Bioavailability of trace elements to terrestrial plants. Soil Ecotoxicol 178

60. Nagajyoti PC, Lee KD, Sreekanth TVM (2010) Heavy metals, occurrence and toxicity for plants: a review. Environ Chem Lett 8(3):199-216. https://doi.org/10.1007/s10311-010-0297-8

61. Navarro-Pedreño J, Almendro-Candel MB, Jordán-Vidal MM, Mataix-Solera J, García-Sánchez E (2003) Mobility of cadmium, chromium, and nickel through the profile of a calcisol treated with sewage sludge in the southeast of Spain. Environ Geol 44(5):545-553. https://doi.org/10.1007/s00254-003-0790-5

62. Norland MR, Veith DL (1995) Revegetation of coarse taconite iron ore tailing using municipal solid waste compost. J. Hazard. Matter., Selected papers presented at the Conference on Hazardous Waste Remediation 41:123-134

63. Norma Oficial Mexicana NOM-147-SEMARNAT/SSA1-2004 (2007) Que establece criterios para determinar las concentraciones de remediación de suelos contaminados por arsénico, berilio, cadmio, cromo hexavalente, mercurio, níquel, plomo, selenio, talio y vanadio. México

64. Oladipo OG, Olayinka A, Awotoye OO (2016) Maize (Zea mays L.) performance in organically amended mine site soils. J Environ Manage 181:435-442. https://doi.org/10.1016/j.jenvman.2016.07.009

65. Pál M, Horváth E, Janda T, Páldi E, Szalai G (2006) Physiological changes and defense mechanisms induced by cadmium stress in maize. J Plant Nutr Soil Sci 169:239-246. https://doi.org/10.1002/jpln.200520573

66. Prommer H, Sun J, Helm L, Rathi B, Siade AJ, Morris R (2018) Deoxygenation prevents arsenic mobilization during deep well injection into sulfide-bearing aquifers. Environ Sci Technol 52(23):13801-13810. https://doi.org/10.1021/acs.est.8b05015

67. Pulford ID, Watson C (2003) Phytoremediation of heavy metal-contaminated land by trees-a review. Environ Int 29:529-540. https://doi.org/10.1016/S0160-4120(02)00152-6 
68. Ritcey GM (1989) Tailings management, problems and solutions in the mining industry. Elsevier Science Publishing Co. Inc., p 970

69. Romero FM, Armienta MA, González-Hernández G (2007) Solid-phase control on the mobility of potentially toxic elements in an abandoned lead/zinc mine tailings impoundment, Taxco, Mexico. Appl Geochem 22:109-127. https://doi.org/10.1016/j.apgeochem.2006.07.017

70. Romero FM, Armienta MA, Gutiérrez ME, Villaseñor G (2008) Factores geológicos y climáticos que determinan la peligrosidad y el impacto ambiental de jales mineros. Rev Int Contam Ambient 24:4354

71. Ruiz HEA, Armienta HMA (2012) Acumulación de arsénico y metales pesados en maíz en suelos cercanos a jales o residuos mineros. Rev Int Contam Ambient 28:103-117

72. Russell SH, Evert RF (1985) Leaf vasculature in Zea mays L. Planta 164:448-458. https://doi.org/10.1007/BF00395960

73. Salt DE, Prince RC, Pickering IJ, Raskin I (1995) Mechanisms of cadmium mobility and accumulation in Indian mustard. Plant Physiol 109(4):1427-1433. DOl:https://doi.org/10.1104/pp.109.4.1427

74. Seregin IV, Kozhevnikova AD (2005) Distribution of Cadmium, Lead, Nickel, and Strontium in Imbibing Maize Caryopses. Russ J Plant Physiol 52:565-569. https://doi.org/10.1007/s11183-0050084-8

75. Seregin IV, Shpigun LK, Ivanov VB (2004) Distribution and Toxic Effects of Cadmium and Lead on Maize Roots. Russ J Plant Physiol 51:525-533. doi:10.1023/B:RUPP.0000035747.42399.84

76. Shen H, Christie P, Li X (2006) Uptake of zinc, cadmium and phosphorus by arbuscular mycorrhizal maize (Zea mays L.) from a low available phosphorus calcareous soil spiked with zinc and cadmium. Environ Geochem Health 28:111-119. https://doi.org/10.1007/s10653-005-9020-2

77. Shi Y, Huang Z, Liu X, Imran S, Peng L, Dai R, Deng Y (2016) Environmental materials for remediation of soils contaminated with lead and cadmium using maize (Zea mays L.) growth as a bioindicator. Environ Sci Pollut Res 23(7):6168-6178. https://doi.org/10.1007/s11356-015-5778-7

78. Shinmachi F, Kumanda Y, Noguchi A, Hasegawa I (2003) Stem-specific cadmium accumulation in cadmium-tolerant Polygonum thunbergii. Soil Sci Plant Nutr 49:363-368. https://doi.org/10.1080/00380768.2003.10410021

79. Souza JF, Dolder H, Cortelazzo AL (2005) Effect of Excess Cadmium and Zinc lons on Roots and Shoots of Maize Seedlings. J Plant Nutr 28:1923-1931. https://doi.org/10.1080/01904160500310435

80. Souza JF, Rauser WE (2003) Maize and radish sequester excess cadmium and zinc in different ways. Plant Sci 165:1009-1022. https://doi.org/10.1016/S0168-9452(03)00289-9

81. Tovar-Sánchez E, Cervantes LT, Martínez C, Rojas E, Valverde M, Ortiz-Hernández ML, MussaliGalante P (2012) Comparison of two wild rodent species as sentinels of environmental contamination by mine tailings. Environ Sci Pollut Res 19(5):1677-1686. https://doi.org/10.1007/s11356-011-0680-4 
82. Tovar-Sánchez E, Cervantes-Ramírez T, Castañeda-Bautista J, Gómez-Arroyo S, Ortiz-Hernández L, Sánchez-Salinas E, Mussali-Galante P (2018) Response of Zea mays to multimetal contaminated soils: a multibiomarker approach. Ecotoxicol 27(8):1161-1177. https://doi.org/10.1007/s10646018-1974-9

83. Unterbrunner R, Puschenreiter M, Sommer P, Wieshammer G, Tlustoš P, Zupan M, Wenzel WW (2007) Heavy metal accumulation in trees growing on contaminated sites in Central Europe. Environ Pollut 148:107-114. https://doi.org/10.1016/j.envpol.2006.10.035

84. Vázquez S, Agha R, Granado A, Sarro MJ, Esteban E, Peñalosa JM, Carpena RO (2006) Use of white lupin plant for phytostabilization of $\mathrm{Cd}$ and As polluted acid soil. Water Air Soil Pollut 177:349-365. https://doi.org/10.1007/s11270-006-9178-y

85. Vielle-Calzada JP, de la Vega OM, Hernández-Guzmán G, Ibarra-Laclette E, Alvarez-Mejía C, VegaArreguín JC, Jiménez-Moraila B, Fernández-Cortés A, Corona-Armenta G, Herrera-Estrella L, HerreraEstrella A (2009) The Palomero genome suggests metal effects on domestication. Sci 326(5956):1078-1078. DOI:10.1126/science.1178437

86. Vollenweider P, Cosio C, Günthardt-Goerg MS, Keller C (2006) Localization and effects of cadmium in leaves of a cadmium-tolerant willow (Salix viminalis L.): Part II Microlocalization and cellular effects of cadmium. Environ Exp Bot 58:25-40. doi:10.1016/j.envexpbot.2005.06.012

87. Walder IF, Chavez WX (1995) Mineralogical and geochemical behavior of mill tailing material produced from lead-zinc skarn mineralization, Hanover, Grant County, New Mexico, USA. Environ Geol 26:1-18. https://doi.org/10.1007/BF00776027

88. Wang J, Jiang Y, Sun J, She J, Yin M, Fang F, Xiao T, Song G, Liu J (2020a) Geochemical transfer of cadmium in river sediments near a lead-zinc smelter. Ecotoxicol Environ Saf 196:110529. https://doi.org/10.1016/j.ecoenv.2020.110529

89. Wang X, Yu S, Jin J, Wang H, Alharbi NS, Alsaedi A, Hayat T, Wang X (2016) Application of graphene oxides and graphene oxide-based nanomaterials in radionuclide removal from aqueous solutions. Sci Bull 061:1583-1593. https://doi.org/10.1007/s11434-016-1168-x

90. Wang J, Liu J, Li H, Chen Y, Xiao T, Song G, Chen D, Wang C (2017) Uranium and thorium leachability in contaminated stream sediments from a uranium mine site. J Geochem Exp 176:85-90. https://doi.org/10.1016/j.gexplo.2016.01.008

91. Wang PC, Li ZG, Liu JL, Bi XY, Ning YQ, Yang SC, Yang XJ (2019) Apportionment of sources of heavy metals to agricultural soils using isotope fingerprints and multivariate statistical analyses. Environ Pollut 249:208-216. https://doi.org/10.1016/j.envpol.2019.03.034

92. Wang J, Zhou Y, Dong X, Yin M, Tsang D, Sun J, Liu J, Song G, Liu Y (2020b) Temporal sedimentary record of thallium pollution in an urban lake: an emerging thallium pollution source from copper metallurgy. Chemosphere 242:125172. https://doi.org/10.1016/j.chemosphere.2019.125172

93. Wang J, She J, Zhou Y, Tsang DCW, Beiyuan J, Xiao T, Dong X, Chen Y, Liu J, Yin M, Wang L (2020c) Microbial insights into the biogeochemical features of thallium occurrence: a case study from 
polluted river sediments. Sci Total Environ 739:139957.

https://doi.org/10.1016/j.scitotenv.2020.139957

94. Wei X, Zhou Y, Jiang Y, Tsang DC, Zhang C, Liu J, Zhou Y, Yin M, Wang J, Shen N, Xiao T, Xiao T (2020) Health risks of metal (loid)s in maize (Zea mays L.) in an artisanal zinc smelting zone and source fingerprinting by lead isotope. Sci Total Environ 742:140321.

https://doi.org/10.1016/j.scitotenv.2020.140321

95. Wenger K, Gupta SK, Furrer G, Schulin R (2002) Zinc Extraction potential of two common crop plants, Nicotiana tabacum and Zea mays. Plant Soil 242:217-225.

https://doi.org/10.1023/A:1016253821174

96. Weryszko-Chmielewska E, Chwil M (2005) Lead-Induced Histological and Ultrastructural Changes in the Leaves of Soybean (Glycine max (L.) Merr.). Soil Sci Plant Nutr 51:203-212. https://doi.org/10.1111/j.1747-0765.2005.tb00024.x

97. Wójcik M, Tukiendorf A (2005) Cadmium uptake, localization and detoxification in Zea mays. Biol Plant 49:237-245. https://doi.org/10.1007/s10535-005-7245-7

98. Wójicik M, Tukendorf A (1999) Cd-tolerance of maize, rye and wheat seedlings. Acta Physiol Plant 21:99-107. https://doi.org/10.1007/s11738-999-0063-3

99. Wong JWC, Ip CM, Wong MH (1998) Acid-forming capacity of lead-zinc mine tailings and its implications for mine rehabilitation. Environ Geochem Health 20:149-155.

https://doi.org/10.1023/A:1006589124204

100. Wong MH (2003) Ecological restoration of mine degraded soils, with emphasis on metal contaminated soils. Chemosphere 50:775-780. https://doi.org/10.1016/S0045-6535(02)00232-1

101. Wu Q, Pagès $L, W u ~ J ~(2016)$ Relationships between root diameter, root length and root branching along lateral roots in adult, field-grown maize. Ann Bot 117(3):379-390.

https://doi.org/10.1093/aob/mcv185

102. Xu Q, Shi G (2000) The toxic effects of single Cd and interaction of Cd with $\mathrm{Zn}$ on some physiological index of [Oenanthe javanica (Blume) DC]. J Nanjing Norm Univ Nat Sci 23(4):97-100

103. Zhao FJ, Lombi E, Breedon T, SPMC (2000) Zinc hyperaccumulation and cellular distribution in Arabidopsis halleri. Plant Cell Environ 23:507-514. https://doi.org/10.1046/j.13653040.2000.00569.x

\section{Tables}

Table 1. Heavy metals and As average concentrations in soils ( $\mathrm{mg} / \mathrm{kg}$ dry weight). 


\begin{tabular}{|c|c|c|c|c|c|c|}
\hline Site & $\mathrm{Fe} \%$ & Zn & $\mathrm{Cu}$ & $\mathrm{Cd}$ & $\mathrm{Pb}$ & As \\
\hline STAX1 & $\begin{array}{l}2.9 \\
(0.5) a\end{array}$ & $\begin{array}{l}687.4 \\
(198.2) b\end{array}$ & $\begin{array}{l}447.1 \\
(107.4) b\end{array}$ & $\begin{array}{l}6.9 \\
(2.4) \mathrm{b}\end{array}$ & $\begin{array}{l}229.6 \\
(50.6) \mathrm{b}\end{array}$ & $\begin{array}{l}46.8 \\
(9.5) a\end{array}$ \\
\hline STAX2 & $\begin{array}{l}3.2 \\
(0.1) a\end{array}$ & $\begin{array}{l}147.2 \\
(17.3) \mathrm{a}\end{array}$ & $\begin{array}{l}62.4 \\
(3.5) a\end{array}$ & $\begin{array}{l}3.5 \\
(0.6) a\end{array}$ & $59.9(0.1) a$ & $\begin{array}{l}22.3 \\
(0.9) a\end{array}$ \\
\hline STAX3 & $\begin{array}{l}9.6 \\
(0.8) b\end{array}$ & $\begin{array}{l}3494.0 \\
(352.4) \mathrm{c}\end{array}$ & $\begin{array}{l}388.1 \\
(32.4) b\end{array}$ & $\begin{array}{l}26.7 \\
(1.9) c\end{array}$ & $\begin{array}{l}3269.7 \\
(53.7) \mathrm{c}\end{array}$ & $\begin{array}{l}192.7 \\
(44.8) \mathrm{b}\end{array}$ \\
\hline $\begin{array}{l}\text { Limit value of NOM- } \\
\text { 147-SEMARNAT-2004 }\end{array}$ & & & & 37 & 400 & 22 \\
\hline $\begin{array}{l}\text { Limit value of WHO } \\
1996 \text { soils }\end{array}$ & & 50 & 36 & 0.8 & 85 & \\
\hline $\begin{array}{l}\text { Limit value of EPA } \\
2002\end{array}$ & & 24.7 & 16.4 & 0.48 & 3.9 & \\
\hline STD & $2.4(4.7)$ & $304.0(3.7)$ & $105.2(7.0)$ & $37.9(0.0)$ & $1100.0(2.7)$ & $107.2(2.5)$ \\
\hline Mon 2711** & 2.89 & 350.4 & 114 & 41.7 & 1162 & 105 \\
\hline Recovery (\%) & 83 & 87 & 92 & 91 & 95 & 100 \\
\hline
\end{tabular}

Different letters in a column correspond to statistically different values $(P<0.05)$. Numbers in parenthesis correspond to standard deviation values $(n=5)$. **Montana (Mon) soil 2711 NIST reported concentration. Detection limits (LD), $\mathrm{mgkg}^{-1}: \mathrm{Fe}=10, \mathrm{Zn}=5, \mathrm{Cu}=5, \mathrm{Cd}=2, \mathrm{~Pb}=20$, and $\mathrm{As}=5$.

Table 2. Concentrations of metals and As ( $\mathrm{mg} / \mathrm{kg}$ of dry weight) in maize organs (root, stem, leaf, and kernel) sampled at 22 weeks of growth. 
$\begin{array}{llllll}\mathrm{Fe} & \mathrm{Zn} & \mathrm{Cu} & \mathrm{Cd} & \mathrm{Pb} & \text { As }\end{array}$

\begin{tabular}{|c|c|c|c|c|c|c|}
\hline $\begin{array}{l}\text { Brace } \\
\text { roots }\end{array}$ & & & & & & \\
\hline STAX1 & $820.6(34.3) a$ & $73.4(6.4) b$ & 78.1(16.8)b & $1.1(32.6) a$ & $14.6(31.7) \mathrm{b}$ & $0.2(68.0) a$ \\
\hline STAX2 & 2651.5(23.9)b & $45.3(8.5) a$ & $17.6(21.2) b$ & $1.0(0.7) a$ & 7.9(23.3)a & $0.7(49.5) b$ \\
\hline STAX3 & $4040.6(34.4) c$ & 2302.7(7.6)c & $82.2(22.0) b$ & 63.2(49.1)b & $23.8 \mathrm{c}$ & $1.6(6.1) c$ \\
\hline \multicolumn{7}{|l|}{ Stem } \\
\hline STAX1 & 13.3(25.6)a & 53.8(71.2)a & $2.6(62.1) a$ & $0.5(2.7) a$ & $3.1(15.2) b$ & $0.1(29.1) a$ \\
\hline STAX2 & $33.5(27.7) \mathrm{b}$ & $52.2(0.7) a$ & $2.0(34.7) a$ & $0.5(0.7) a$ & $1.5(1.5) a$ & $0.3(30.4) b$ \\
\hline STAX3 & $52.8(56.9) \mathrm{c}$ & 1521.5(3.8)b & $5.3(26.4) b$ & $3.6(10.1) b$ & $3.8(10.8) b$ & $0.1(37.5) a$ \\
\hline \multicolumn{7}{|l|}{ Leaf } \\
\hline STAX1 & 145.1(5.7)a & $47.3(0.8) a$ & $10.8(52.0) \mathrm{b}$ & $0.7(46.5) a$ & $5.2(38.8) a b$ & $0.2(14.5) a$ \\
\hline STAX2 & 177.6(76.9)b & $47.4(50.5) a$ & $6.2(16.3) a$ & $0.7(46.5) a$ & $4.0(36.9) a$ & $0.3(7.7) a b$ \\
\hline STAX3 & $186.9(16.5) b$ & $287.4(31.8) b$ & $6.8(10.1) a$ & $1.7(60.6) b$ & $6.4(3.8) b$ & $0.4(1.7) b$ \\
\hline \multicolumn{7}{|l|}{ Kernel } \\
\hline STAX1 & $30.5(10.0) a$ & $41.9(21.8) b$ & $5.2(32.9) b$ & 1.4(47.6)b & $0.5(15.0) a$ & $0.2(59.1) b$ \\
\hline STAX2 & 26.2(20.9)a & $29.0(29.7) a$ & 2.8 (18.7)a & $0.5(55.3) a$ & $0.6(3.2) a$ & $0.0(76.8) a$ \\
\hline STAX3 & 28.3(1.3)a & $35.4(69.8) a$ & $4.0(41.0) a$ & $0.9(48.0) a$ & $0.5(18.7) a$ & $0.1(10.1) b$ \\
\hline
\end{tabular}

Different letters in a column correspond to statistically different values $(P<0.05)$. Numbers inside parenthesis correspond to standard deviation values $(n=3)$. Detection limits (LD), $\mathrm{mgkg}^{-1}: F e=2.5, Z n=2.5$, $C u=2.5, C d=0.05, P b=0.05$, and $A s=0.015$.

Table 3. Morphological characteristics of vegetative and generative organs in plants grown for 22 weeks in STAX1, STAX2, and STAX3 soils. 


\begin{tabular}{|c|c|c|c|}
\hline Parameters & Sites & & \\
\hline Morphology and biomass & STAX1 $n=45$ & STAX2 $n=45$ & STAX3 $n=45$ \\
\hline Total fresh weight -aerial part ( $\mathrm{g}$ ) & $52(25) c$ & $11(3) b$ & $4(2) a$ \\
\hline Total dry weight- aerial part (g) & $21(10) c$ & $4(2) b$ & $2(1) a$ \\
\hline Fresh weight- root (g) & 17(7)c & $4(2) b$ & $2(0.4) a$ \\
\hline Dry weight-root (g) & $5(3) c$ & $1(0.4) \mathrm{b}$ & $1(0.3) \mathrm{a}$ \\
\hline Biomass* (\%) & $41(15) a$ & $38(18) b$ & $41(22) a$ \\
\hline Number of phytomers & 13(6)c & $10(6) b$ & $8(3) a$ \\
\hline Longest leaf length (cm) & $73(30) c$ & $42(23) b$ & 25(12)a \\
\hline Ears & STAX1 $n=76$ & STAX2 $n=76$ & STAX3 $n=32$ \\
\hline Length $(\mathrm{cm})$ & $10(3)^{b}$ & $8(2)^{a}$ & $8(2)^{a}$ \\
\hline Dry weight of ears (g) & $3(2)^{c}$ & $0.5(0.4)^{b}$ & $0.2(0.1)^{a}$ \\
\hline Normal appearance (\%) & $78(12)^{c}$ & $46(15)^{\mathrm{b}}$ & $28(9)^{a}$ \\
\hline Dry weight of kernels (g) & $0.18(0.01)^{b}$ & $0.11(0.02)^{\mathrm{a}}$ & $0.06(0.002)^{a}$ \\
\hline Tassel & STAX1 $n=64$ & STAX2 n=46 & STAX3 $n=13$ \\
\hline Length $(\mathrm{cm})$ & 15(5)c & $7(4) b$ & $4(3) a$ \\
\hline Number of branches & $5(3) b$ & $2(1) a$ & $1(0.3) a$ \\
\hline Normal appearance (\%) & $84(12) c$ & $52(14) b$ & $8(4) a$ \\
\hline
\end{tabular}

Different letters in a row correspond to statistically different values $(P<0.05)$. Numbers inside parenthesis indicate standard deviation values. *Biomass $(\%)=\left(\right.$ Fresh weight-dry weight) in percentage ${ }^{1}$

Table 4. Morphometric analysis of roots and stems on transverse sections and of leaf surface in plants grown for 22 weeks in STAX1, STAX2, and STAX3 soils. 


\begin{tabular}{|c|c|c|c|}
\hline Morphometric parameters & Sites & & \\
\hline Shoot-borne brace roots & STAX1 & STAX2 & STAX3 \\
\hline Major root diameter $(\mu \mathrm{m})$ & $1580(533)^{\mathrm{c}}$ & $1287(313)^{b}$ & $1200(177)^{a}$ \\
\hline Minor root diameter $(\mu \mathrm{m})$ & $1450(425)^{\mathrm{c}}$ & $1285(386) b$ & $1163(185)^{\mathrm{a}}$ \\
\hline Shortest (minor) vascular bundle diameter $(\mu \mathrm{m})$ & $833(365)^{c}$ & $699(176)^{\mathrm{b}}$ & $640(68)^{a}$ \\
\hline Longest (major) vascular bundle diameter $(\mu \mathrm{m})$ & $908(478)^{\mathrm{c}}$ & $763(245)^{b}$ & $655(94)^{a}$ \\
\hline Number of metaxylem sectors per section & $25(2)^{b}$ & 15(3)a & $12(2)^{a}$ \\
\hline Stem & STAX1 & STAX2 & STAX3 \\
\hline Diameter (mm) & $4.5(0.8)^{\mathrm{c}}$ & $2.6(0.6)^{b}$ & $1.6(0.4)^{\mathrm{a}}$ \\
\hline Number of vascular bundles & $11(3)^{c}$ & $7(4)^{b}$ & $5(2)^{a}$ \\
\hline Parenchyma cell diameter $(\mu \mathrm{m})$ & $106(63)^{c}$ & $77(24)^{b}$ & $35(12)^{\mathrm{a}}$ \\
\hline Leaf & STAX1 & STAX2 & STAX3 \\
\hline Stomata number (adaxial) & $5(1) a$ & $6(2) a$ & $5(2) a$ \\
\hline Stomata number (abaxial) & $9(2) a$ & $9(1) a$ & $11(3) b$ \\
\hline Epidermal cell length $(\mu \mathrm{m})$. & $88(13) b$ & $86(18) b$ & $68(14) a$ \\
\hline
\end{tabular}

Different letters in rows correspond to statistical different values $(P<0.05)$. Numbers inside parenthesis correspond to standard deviation values $n=20$.

\section{Supplementary}

Appendices A and B are not available with this version.

\section{Figures}




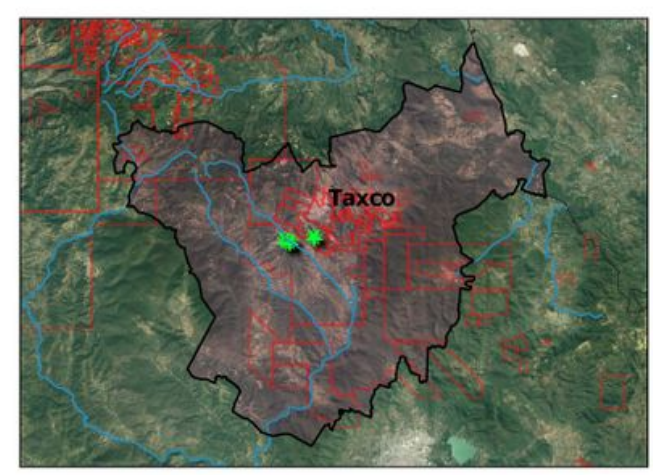

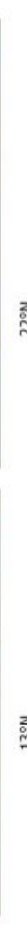
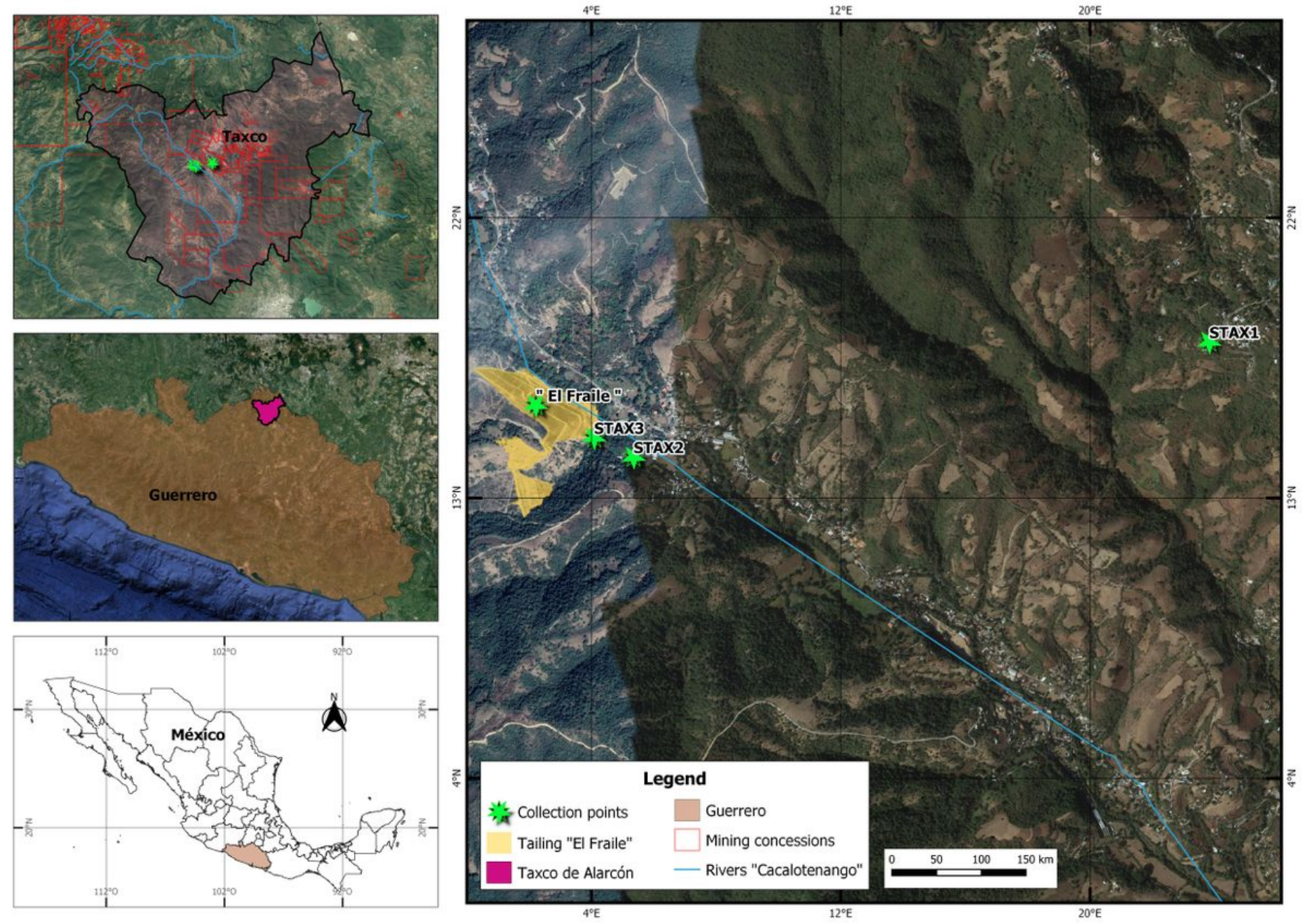

Figure 1

Location of sampled soils in Taxco, Guerrero, México 


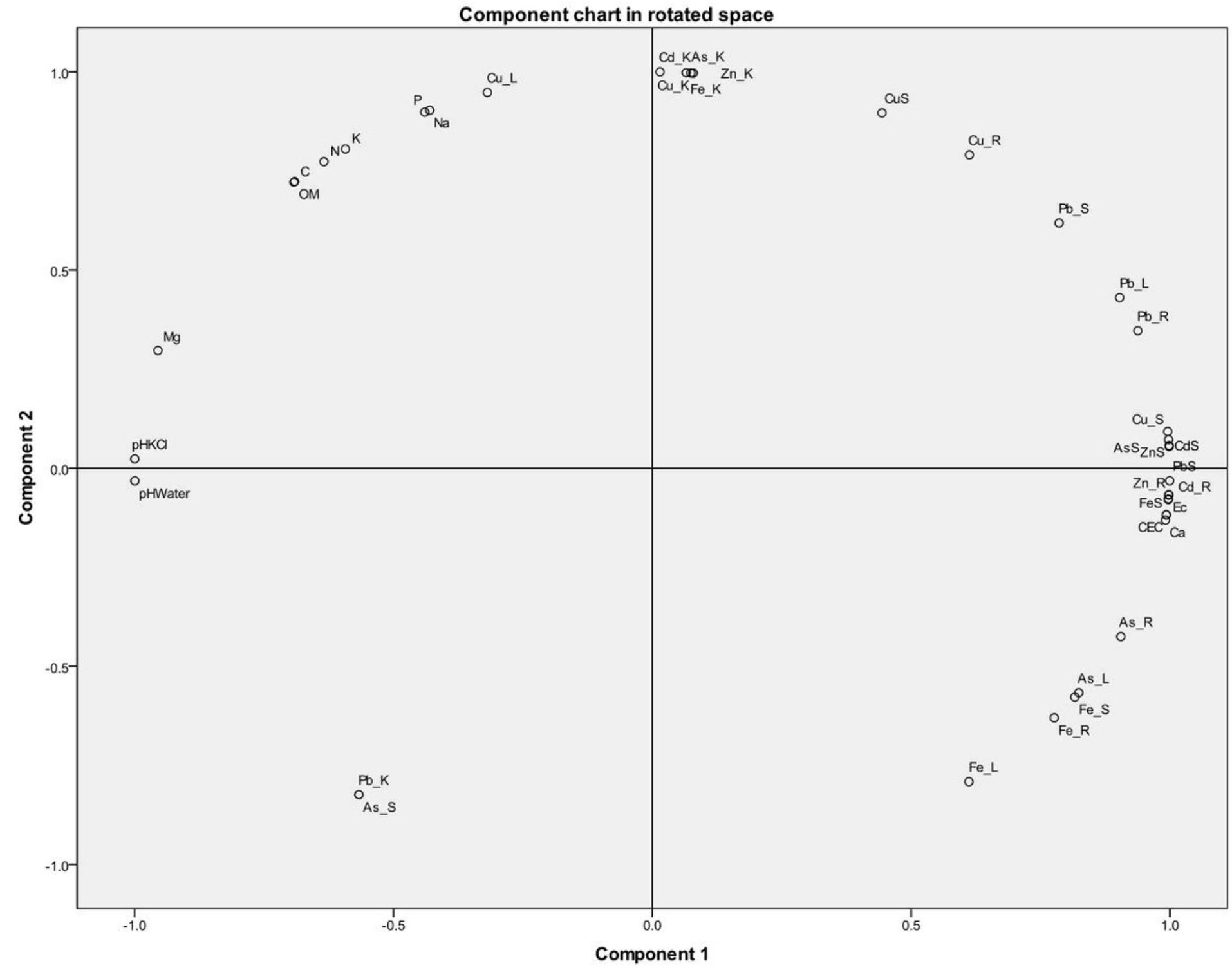

Figure 2

The principal component analysis of heavy metal and As content in maize organs. abbreviations: _K is Kernel; _L is Leaves; _R is Roots; _S is Soils 


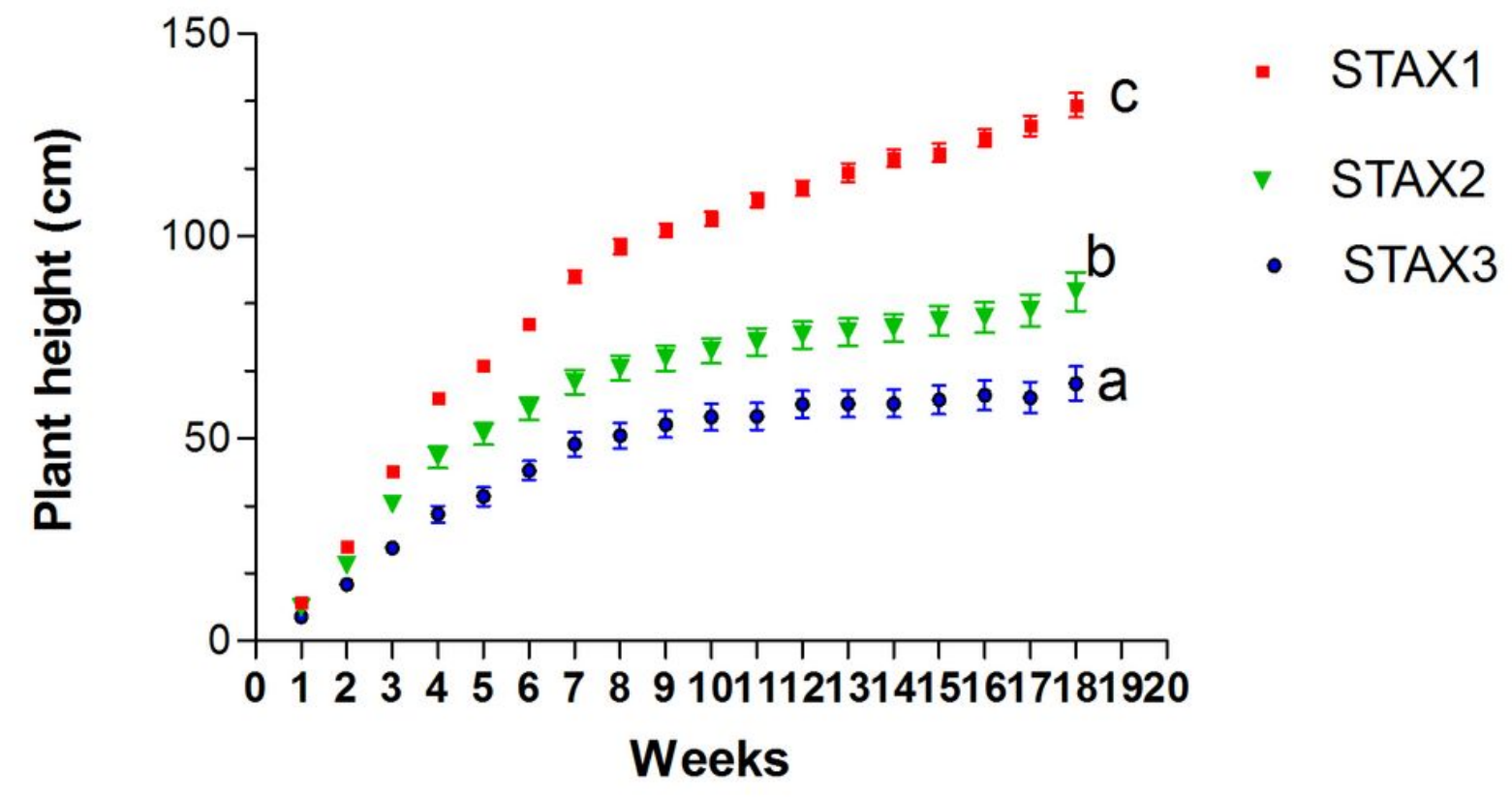

Figure 3

Changes in height of maize plants during 22 weeks. Different letters indicate statistical difference $(P<0.05), n=60, S E$. 


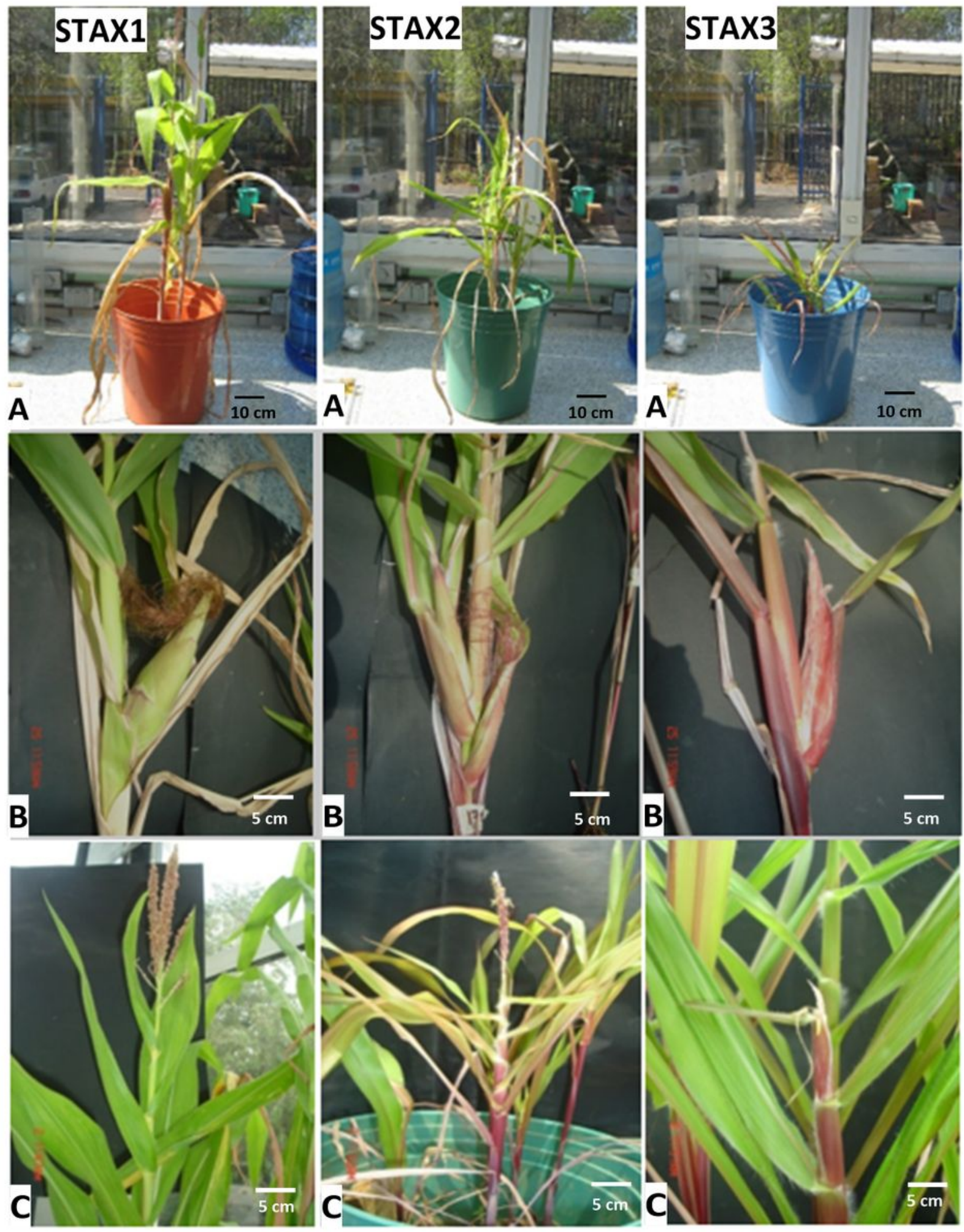

Figure 4

Maize plants grown during 22 weeks in the studied soils: STAX1, STAX2, and STAX3 showing visible morphological differences. A) plant appearance. B) ear morphology. C) tassel morphology. 


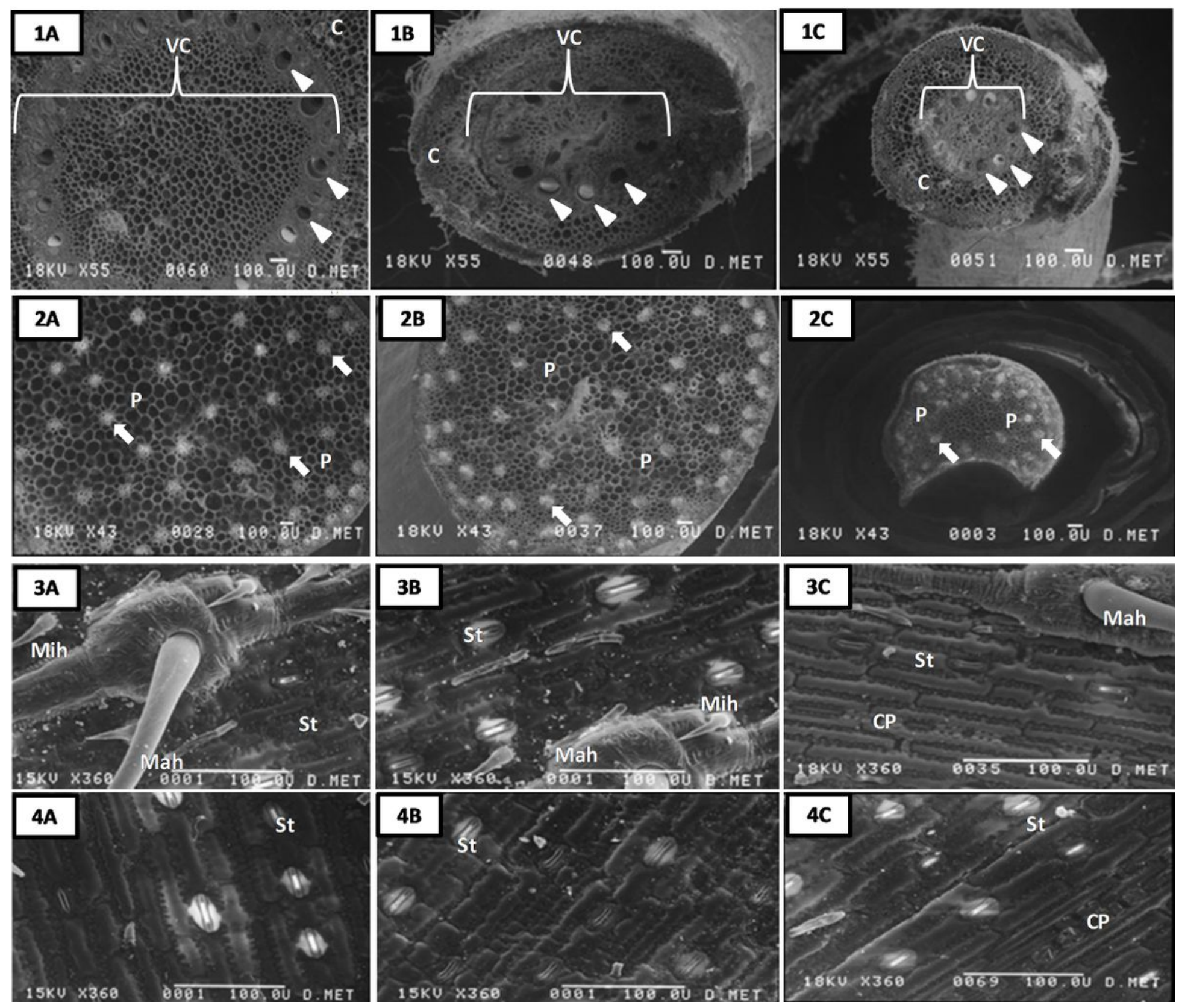

Figure 5

Scanning electron microscopy analysis of plants grown in different soils samples. A) STAX1; B) STAX2, C) STAX3, grown in the three substrates. Microphotographs. 1) Transverse sections of roots (55x); 2 ) stem, (43x); 3) abaxial leaf surface and 4) 